\title{
CARBONATE CHEMISTRY CHARACTERIZATION IN A LOW-INFLOW ESTUARY WITH RECENT SEAGRASS LOSS
}

\author{
A Thesis \\ presented to \\ the Faculty of California Polytechnic State University, \\ San Luis Obispo
}

\author{
In Partial Fulfillment \\ of the Requirements for the Degree \\ Master of Science in Civil/Environmental Engineering
}

by

Jolie Higgins

June 2019 
(c) 2019

Jolie Higgins

ALL RIGHTS RESERVED 
COMMITTEE MEMBERSHIP

TITLE: Carbonate Chemistry Characterization in a LowInflow Estuary with Recent Seagrass Loss

AUTHOR: Jolie Higgins

DATE SUBMITTED: June 2019

COMMITTEE CHAIR: Rebekah Oulton, Ph.D., PE

Assistant Professor of Civil and Environmental

Engineering

COMMITTEE MEMBER: Emily Bockmon, Ph.D.

Assistant Professor of Chemistry and Biochemistry

COMMITTEE MEMBER: Yarrow Nelson, Ph.D.

Professor of Civil and Environmental Engineering 


\section{ABSTRACT}

Carbonate Chemistry Characterization in a Low-Inflow Estuary with Recent Seagrass Loss Jolie Higgins

Estuaries are dynamic environments that are strongly affected by natural variability, as well as direct and indirect anthropogenic impacts. A better understanding of the drivers of carbon fluxes and biogeochemical variability in estuarine systems is needed, particularly with the increasing threat of ocean acidification. Morro Bay in Central California is a small nationally protected estuary, with seasonally low freshwater inputs. Since 2007, the bay has experienced a significant loss of native seagrass, Zostera marina, which is an important component of the marine ecosystem. Because seagrass photosynthesis decreases carbon dioxide and increases oxygen in the water column, the loss of seagrass has the potential to substantially change short-term carbonate chemistry and long-term carbon fluxes of an estuary. The spatial variability of carbonate chemistry was measured in Morro Bay using ship-board surveys during the low-inflow summer season and measured the temporal variability by collecting samples close to the shore from July to November. Discrete samples show an increase in total alkalinity and dissolved inorganic carbon in the mid and back bay regions, historically dominated by seagrass. Slightly lower total alkalinity and dissolved inorganic carbon were observed in the Fall season compared to the low-inflow Summer season. Analysis of the relative modification of alkalinity and dissolved inorganic carbon, paired with salinity and temperature data, contributes to an understanding of the drivers of the observed carbonate variability. This understanding may provide clues to the causes and effects of observed changes to the bay with seagrass loss. More broadly, it will inform the vulnerability of other low-inflow estuaries to future acidification and highlight the role seagrasses play in mitigating local acidification.

Keywords: low-inflow estuary, Morro Bay Estuary, carbonate chemistry, ocean acidification, eelgrass loss 


\section{ACKNOWLEDGMENTS}

This research would not be possible without the support of everyone involved. I first want to thank my thesis committee for taking their time to be a part of this process. Thank you to Dr. Bockmon for taking me on without hesitation, despite me being new to the marine science world. You have been such a wonderful mentor and teacher to me throughout this entire process. Thank you for your endless encouragements, patience and feedback through this process. Thank you Dr. Oulton for allowing me to be a part of this cross over project with Marine Science and guiding me through, not only the past year of grad school, but the past four years at Cal Poly. I would also like to thank Dr. Nelson for being a part of the committee and inspiring me to be passionate about water chemistry.

I also want to acknowledge the financial support received for this project including: Cal Poly Research, Scholarly and Creative Activities (RSCA) Grant Program, supported by funds from the Provost's Office and the Chancellor's Office, NOAA Grant \#NA18OAR4170073 and California Sea Grant College Program Project \#R/HCE-07, William and Linda Frost Fund. LSAMP and the Cal Poly Graduate Program contributed funding for the opportunity to present this research at the ASLO 2019 conference in Puerto Rico

A special thanks is due to Cal Poly Center for Coastal Marine Science, particularly Thomas Moylan, Jason Felton, \& lan Robbins for their support in boating and field work. Additionally, thank you to the undergraduate chemist and marine science students for sample collection assistance.

Lastly, I want to thank my family, especially my Mom and Dad, for all the support and words of encouragement throughout this entire process. 


\section{TABLE OF CONTENTS}

TABLE OF CONTENTS

Page

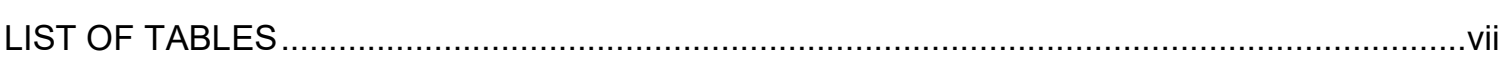

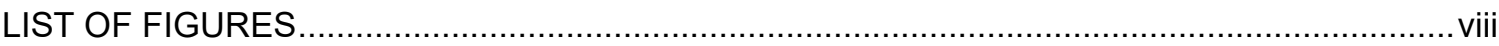

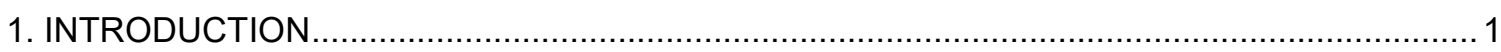

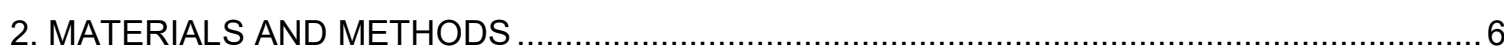

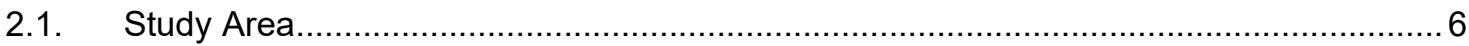

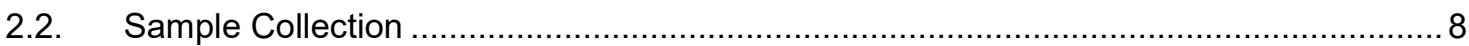

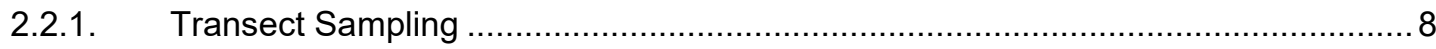

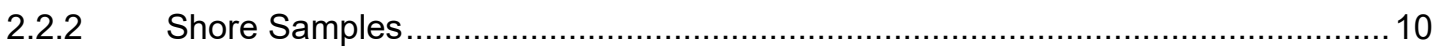

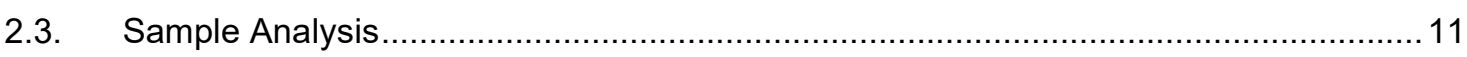

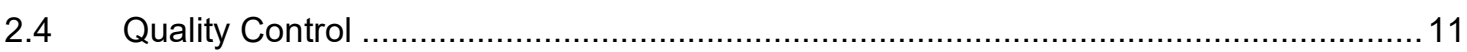

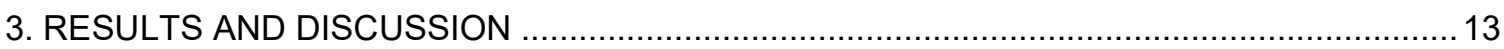

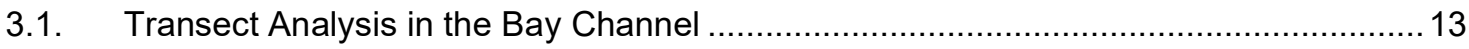

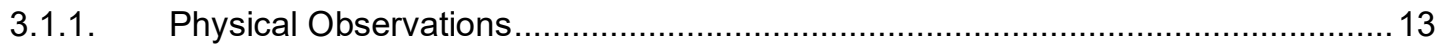

3.1.2. Spatial Observations within the Bay Channel ............................................... 15

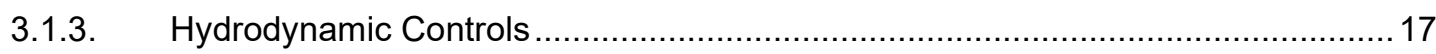

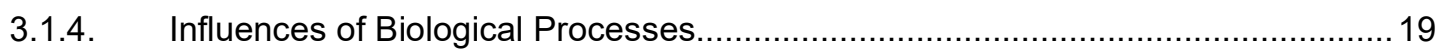

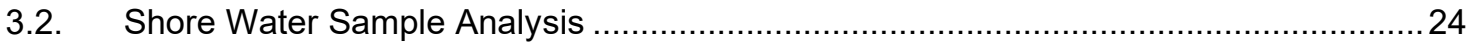

3.2.1. Salinity and Temperature in the Front and Back Bay .................................... 24

3.2.2. Carbonate Chemistry in the Front and Back Bay............................................ 26

3.2.3. Seasonal Changes in Carbonate Chemistry ................................................... 29

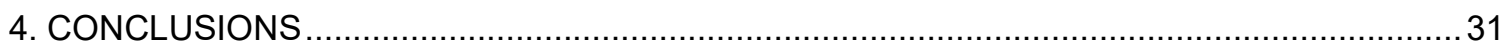

4.1. Processes that Affect Carbonate Chemistry in the Estuary .......................................... 31

4.2. Effect of Estuarine Carbonate on the Global Carbon Cycle ....................................... 34

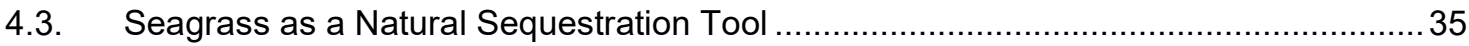

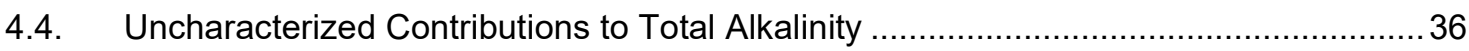

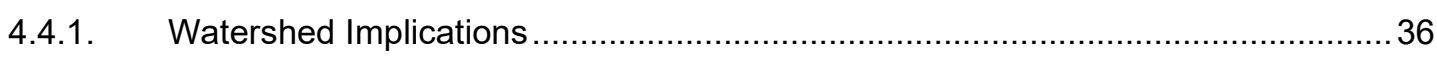

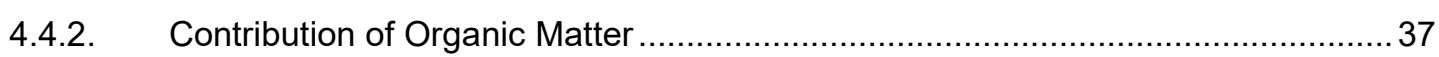

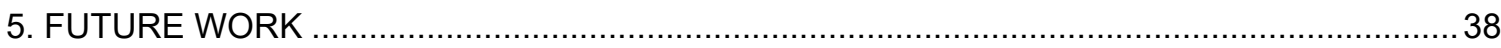

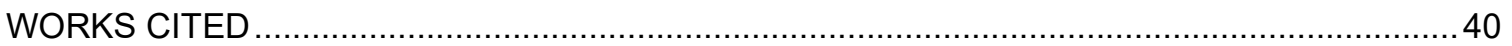




\section{LIST OF TABLES}

Table

Page

1. Differences Between High and Low Tide for $\mathrm{nDIC}$ and $\mathrm{pH}$ Averages................................22 


\section{LIST OF FIGURES}

Figure

Page

1. Satellite Aerial Photo of the Morro Bay Estuary .....

2. Location of the Ten Transect Stations Collected via a Boat (P1-P10) and the Six Shore Stations (S1-S6) During High and Low Tide in the Morro Bay Estuary. ................................ 8

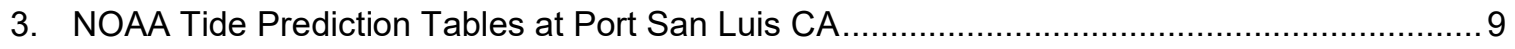

4. Salinity Profiles of Transect Samples Taken from the CTD Casts..................................... 13

5. Temperature versus Distance from the Mouth Station (P1) at Both High and Low Tide During Early, Mid and Late Summer

6. Alkalinity (ALK), Dissolved Inorganic Carbon (DIC) and In-Situ pH Measurements in Relation to the Distance from the Mouth at both High and Low Tide during Early, Mid and Late Summer 15

7. ALK (Top) and Salinity (Bottom) for Early, Mid and Late Summer at High and Low Tide ...... 17

8. DIC Normalized ( $\mathrm{nDIC}$ ) to the Oceanic End-Member Salinity of 34 versus pH Corrected for In-Situ Temperatures at High and Low Tide during Early, Mid and Late Summer 19

9. Contribution of Biological Modifications to Alkalinity (nALK) at High and Low Tide in Relation to the Distance from the Bay Mouth during Early, Mid and Late Summer. .20

10. Normalized Dissolved Inorganic Carbon ( $\mathrm{nDIC}$ ) versus Normalized Alkalinity (nALK) for Early, Mid and Late Summer at High and Low Tide 22

11. Temperature (Top) and Salinity (Bottom) for Shore Stations (S1-S6) Over the Season (July through November).

12. Average ALK and DIC (Top) and Salinity and $\mathrm{pH}_{\mathrm{T}}$ (Bottom) for July through November Sampling Days with Error Bars Representing the Standard Deviation.

13. nAlkalinity During the Shore Sampling Days Relative to the Shore Stations within the Bay .. 28

14. ALK, DIC and In-Situ pH versus the Sampling Dates (July through November) for Each Shore Station (S1-S6)

15. Simple Box-Model Displaying the Various Inputs into the Bay. 31

16. Simple Schematic of the Role Seagrass Plays in Mitigating Water Acidity 35 


\section{Chapter 1}

\section{INTRODUCTION}

Anthropogenic carbon dioxide from burning fossil fuels is changing the world's climate, acidifying the world's oceans, and threatening marine ecosystems. Worldwide, thirty percent of anthropogenic carbon dioxide $\left(\mathrm{CO}_{2}\right)$ is sequestered by the oceans, twenty percent is taken up by the terrestrial biosphere and the last half remains in the atmosphere (Pimenta \& Grear, 2018; Khatiwala et al, 2009; Sabine et al, 2004). Climate change induced by increased anthropogenic $\mathrm{CO}_{2}$ is affecting the frequency of rainfall events, altering the temperatures required for evapotranspiration and increasing sea levels, further impacting and amplifying the effects of ocean acidification on marine environments (Bauer et al., 2013; Paulsen et al., 2017). The combined effects of climate change are even more magnified in coastal environments (Pacella et al., 2017).

When $\mathrm{CO}_{2}$ dissolves into the ocean, it increases the inorganic carbon content of the ocean, also known as total dissolved inorganic carbon (DIC). $\mathrm{CO}_{2}$ reacts with water and dissociates into bicarbonate $\left(\mathrm{HCO}_{3}{ }^{-}\right)$and carbonate $\left(\mathrm{CO}_{3}^{2-}\right)(\mathrm{Eq} 1 \& 2)$.

$$
\begin{array}{cl}
\mathrm{CO}_{2}(a q)+\mathrm{H}_{2} \mathrm{O}(l)=\mathrm{H}^{+}(a q)+\mathrm{HCO}_{3}^{-}(a q) & \text { Equation (1) } \\
\mathrm{HCO}_{3}^{-}=\mathrm{H}^{+}(a q)+\mathrm{CO}_{3}^{2-}(a q) & \text { Equation (2) }
\end{array}
$$

Each dissociation releases a hydrogen ion $\left(\mathrm{H}^{+}\right)$and increases the acidity of the water (Pimenta \& Grear, 2018). For estuarine systems, the acidity is expressed using the total hydrogen scale $\left(\mathrm{pH}_{\mathrm{T}}\right)$ which includes the concentration of free $\mathrm{H}^{+}$ions (Pimenta \& Grear, 2018) (Eq 3).

$$
p H=-\log \left[H^{+}\right]
$$

It is estimated that the average surface seawater $\mathrm{pH}$ in oceanic, coastal and estuarine systems worldwide is approximately $8.1 \pm 0.1$ (Millero, 2007; Pimenta \& Grear, 2018). 
Total alkalinity (ALK) is the amount of seawater chemical constituents in the water that can react with an acid and convert it to an uncharged species, also referred to as the water's buffering capacity (Dickson, 2016; Pimenta \& Grear, 2018) (Eqn 4).

$$
\begin{aligned}
& {[\mathrm{ALK}]=\left[\mathrm{HCO}_{3}^{-}\right]+2\left[\mathrm{CO}_{3}^{2-}\right]+\left[\mathrm{B}(\mathrm{OH})_{4}^{-}\right]+\left[\mathrm{OH}^{-}\right]+\left[\mathrm{HPO}_{4}^{2-}\right] \quad \text { Equation (4) } } \\
&+2\left[\mathrm{PO}_{4}^{3-}\right]+\left[\mathrm{SiO}(\mathrm{OH})_{3}^{-}\right]+\left[\mathrm{NH}_{3}\right]+\left[\mathrm{HS}^{-}\right]+\ldots \\
&-\left[\mathrm{H}^{+}\right] \mathrm{F}-\left[\mathrm{HSO}_{4}^{-}\right]-[\mathrm{HF}]-\left[\mathrm{H}_{3} \mathrm{PO}_{4}\right]-\left[\mathrm{H}^{+}\right] \ldots
\end{aligned}
$$

Hunt et al. further defines ALK as the summation of carbonate (C ALK) and non-carbonate species (NC ALK) (2011) (Eqn 5).

$$
[A L K]=[C A L K]+[N C A L K]+\left[\mathrm{OH}^{-}\right]-\left[H^{+}\right] \quad \text { Equation (5) }
$$

C-ALK is the sum of $\mathrm{HCO}_{3}$ and $\mathrm{CO}_{3}{ }^{2-}$ concentrations. $\mathrm{NC}-\mathrm{ALK}$ is the sum of non-carbonate species, or organic contributions, such as boron, phosphorous, nitrogen, silicon and humic acids (Hunt et al, 2011). Currently there is an incomplete understanding of how other acid-base systems, for example uncharacterized organic acids from bacterial cells and phytoplankton, contribute to seawater total alkalinity (Kim et al., 2006).

$\mathrm{DIC}, \mathrm{pH}_{\mathrm{T}}$ and $\mathrm{ALK}$ parameters together are referred to as seawater carbonate chemistry. It is clear that an increase in $\mathrm{DIC}$ from atmospheric $\mathrm{CO}_{2}$ and the resulting decrease in $\mathrm{pH}$ will have an impact on marine ecosystems (Doney et al., 2009; Cryonack et al. 2017). For example, shelled organisms such as mollusks, corals and sea urchins have more difficulty calcifying due to the decrease in carbonate ion availability that is a result of ocean acidification (Doney et al., 2009). A rise in acidity levels can disintegrate organisms' shells, which releases calcium carbonate $\left(\mathrm{CaCO}_{3}\right)$, a major building block in shell formation, and increases the ALK of the water (Cryonak et al. 2017). 
The effects of acidification are especially variable and further amplified in estuarine environments compared to open ocean systems (Bauer et al., 2013). Estuaries are unique because they receive a mixture of organic and inorganic compounds from terrestrial materials transported via freshwater as well as seawater inputs from the adjacent ocean (referred to as the oceanic endmember). This mix of source waters creates unique habitats for specific organisms such as seagrasses (Bauer et al., 2013).

Absorption from the atmosphere is not the only source of $\mathrm{CO}_{2}$ in estuaries. DIC sources include respiration from biological activity and inputs from rivers, wetlands and sediments. Estuaries tend to experience increased levels of photosynthesis and respiration compared to the open ocean due to their varying tides and shallow water depths that facilitate increased biological activity (Pacella et al., 2017). Another process that occurs in the estuarine environment is $\mathrm{CO}_{2}$ burial in sediment. It was observed that mud can store carbon more easily compared to sandy areas, thus vegetation contributes differently to overall carbon storage depending on bottom composition (Nielsen et al., 2018). Increased urbanization around estuaries can also significantly impact the water chemistry. Eutrophication, a result of nutrient loading caused by increased runoff from urbanization and agriculture, can increase phytoplankton growth at the top of the water column. The resulting respiration of this bloom can create a low oxygen environment, known as hypoxia, and releases $\mathrm{CO}_{2}$ from respiratory processes (Cai et al.,2011). Due to the tremendous internal spatial and temporal heterogeneity in carbon processing and fluxes in an estuary, tracking the net carbon balance is complicated (Bauer et al., 2013).

One important characteristic of some estuarine systems is the presence of seagrass meadows, which play a vital role in the overall health of an estuary. Meadows provide natural habitats for organisms such as clams and sea urchins, the diet of the Southern sea otter. They are crucial for feeding and nursery ground for fish, such as the speckled sanddab (Citharichthys stigmaeus), and invertebrates, such as the Washington clam (Saxidomus nutalli) (US Army Corps, 2013). 
Seagrasses are known to be biological filters for bacterial pathogens, improving the local water quality (Koweek et al 2018). Seagrass beds also provide protection against coastal erosion. Their leaves enhance sedimentation rates of particles in the water column and below ground tissues help stabilize surrounding sediments to further prevent erosion (Rasmusson et al., 2017). Not only are seagrasses vital to ecosystem health, but they also help mitigate atmospheric $\mathrm{CO}_{2}$ through sequestration. Seagrass meadows are commonly referred to as "blue carbon" sinks, referring to their effectiveness to decrease DIC concentrations via photosynthesis (Cyronak et al., 2018). The global rate of carbon sequestration into seagrass meadows has been estimated to be

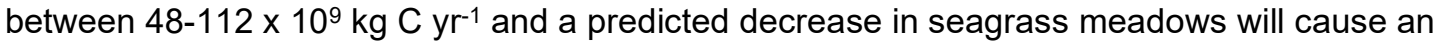
estimated release of $100 \times 10^{9} \mathrm{~kg} \mathrm{yr}^{-1}$ of carbon back into the atmosphere (Johannessen \& Macdonald, 2016).

Daily $\mathrm{pH}_{\mathrm{T}}$ and DIC levels fluctuate in conjunction with seagrass bed metabolic rates. Primary production during the day, via photosynthesis and assimilation, draw down $\mathrm{CO}_{2}$ concentrations and increase $\mathrm{pH}$. The opposite occurs at night when net respiration releases $\mathrm{CO}_{2}$ and decreases рHт. Through photosynthesis, the beds provide necessary oxygen to shallow water areas (Rasmusson et al., 2017). Analysis of seagrass habitats in Puget Sound, WA found $\mathrm{pH}_{\mathrm{T}}$ to be significantly correlated with $\mathrm{O}_{2}$, indicating the role of primary production and respiration in temporal carbonate chemistry variability (Pacella et al 2017). Amplified tidal changes through the day within an estuarine system also impact $\mathrm{pH}$ fluctuations in and around seagrass beds. For example, a lower tide during the day typically results in increased primary production due to the shallow water depth allowing for increased light for photosynthesis (Cyronak et al., 2018). Carbonate chemistry within an estuary also fluctuates throughout the season. In a recent study analyzing the Chesapeake Bay in Virginia, Brodeur et al found the smallest difference in DIC and ALK between the back and mid bay regions during Fall and Winter months, due to cooler temperatures and increased freshwater inputs, compared to the warmer temperatures and lower freshwater inputs observed during the Summer months (Brodeur et al, 2019). 
Estuaries have complex hydrodynamic processes from rapid tidal changes, fluctuating freshwater inputs, and unique estuarine circulation (Pacella et al., 2017). These physical processes affect mixing, water column depth, and local residence times and cause differences in carbonate chemistry throughout an estuary (Duarte et al, 2013). A study in Mission Bay located in San Diego, California, observed spatial differences in $\mathrm{pH}$ of 0.06 to 0.33 due to differences in tidal depth, with low tides undergoing more intense $\mathrm{pH}$ fluctuations. Paulsen et al. observed an increase greater than $2000 \mu \mathrm{mol} \mathrm{kg}{ }^{-1}$ in DIC and ALK across the San Dieguito Lagoon in Southern California (2017).

The objective of this work is to observe and understand the broad physical and biological drivers of carbonate chemistry in Morro Bay. Very little research has been done studying the impacts of ocean acidification on small coastal estuaries with little freshwater input, such as Morro Bay. This case study provides initial observations of the spatial and temporal heterogeneity of estuarine carbonate chemistry and will allow for documentation of any observed effects of climate change in the future. Through this work, we aim to contribute to an understanding of how the loss of eelgrass meadows is altering the carbonate chemistry within the bay, including its natural buffering capacity. 
Chapter 2

MATERIALS AND METHODS

\subsection{Study Area}

Morro Bay is a nationally protected estuary located in California's Central Coast and is classified as a short, low-inflow freshwater estuary. The bay is approximately $6 \mathrm{~km}$ long from the mouth, closest to the ocean, to the back bay, near the city of Los Osos (Figure 2.1). To the west, the estuary is bordered by a four-mile vegetated sandspit separating Morro Bay from the open Pacific Ocean (State of the Bay, 2017) (Figure 2.1). The estuary consists of a $194.25 \mathrm{~km}^{2}$ watershed comprised of two major sub-watersheds that drain into two low-inflow freshwater sources, Los Osos and Chorro creeks (Morro Bay NEP, 2012). Morro Bay's current watershed includes approximately $60 \%$ ranchland, $19 \%$ brushland, $7 \%$ urban areas, $7 \%$ agriculture crops and $7 \%$ woodland (US Army Corps, 2013).

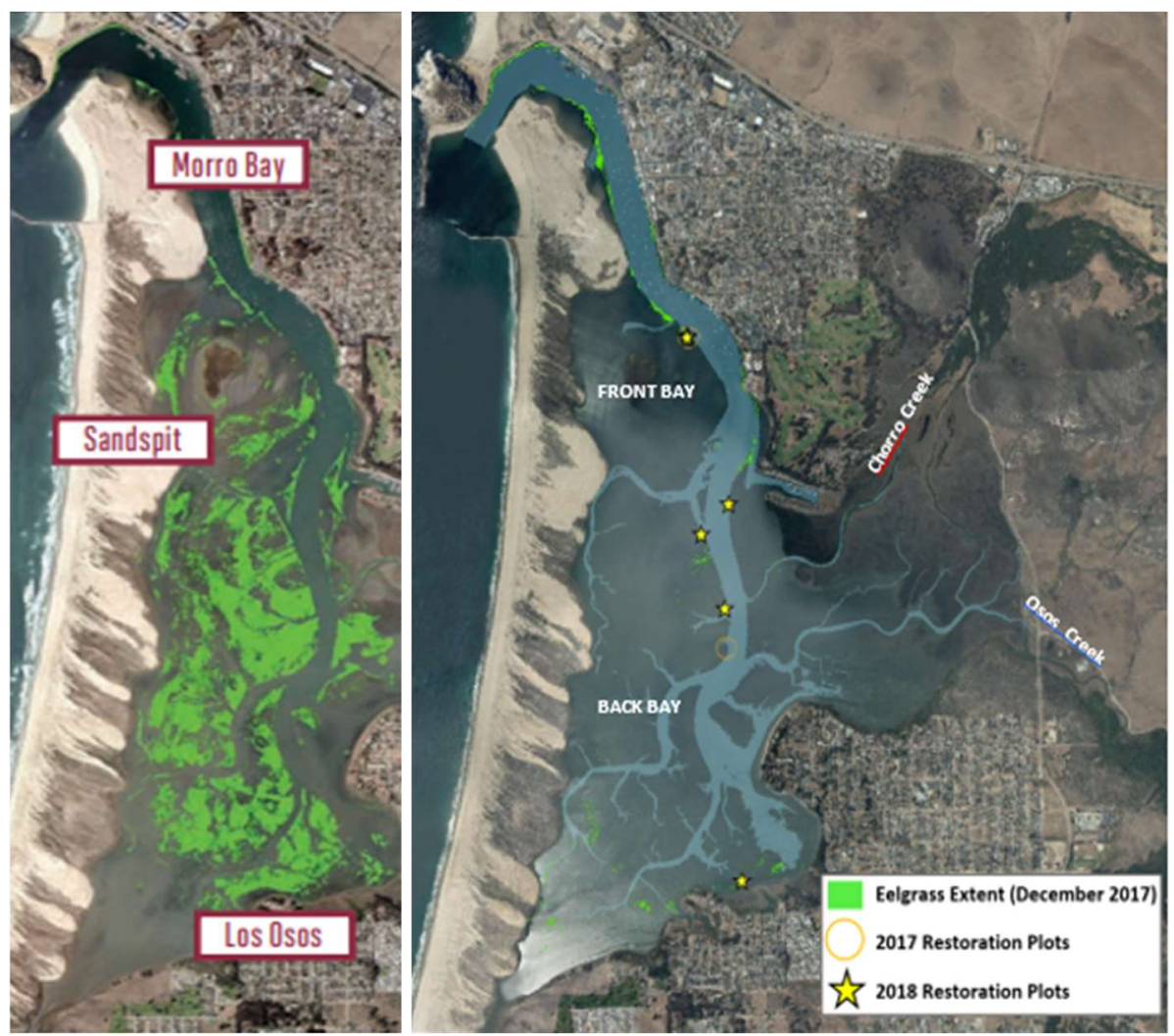

Figure 1. Satellite Aerial Photo of the Morro Bay Estuary. Green shading indicates eelgrass bed extents in 2007 (left) and 2017 (right). 
The estuary is broken up into the "front bay" and the "back bay," each distinguished by their physical and chemical differences (Figure 2.1) (Walter, 2017). Due to the unique tidal flushing observed in the estuary and low freshwater input during the Summer season, the back bay has slightly higher salinity waters compared to the front bay, characterizing the bay as an "inverted estuary" (Walter, 2017). However, the opposite occurs during the rainier Fall season which causes an overall decrease in salinity towards the back bay, as expected for a typical estuary.

Morro Bay has experienced significant loss of the native seagrass beds, Zostera marina (Z. marina), commonly referred to as eelgrass. In 2007 , there was a total of 344 acres of $Z$. marina. Between 2013-2015, there was documented to be less than 20 acres in Morro Bay (State of the Bay, 2017) (Figure 2.1). The estuary is comprised of approximately 2,300 acres, or 9.31 $\mathrm{km}^{2}$, of shallow, intertidal and subtidal habitat (State of the Bay, 2017). Z. marina is currently located primarily in the shallow subtidal zones near the mouth of the bay, along the edges of the channel, and in the intertidal region of the back bay (Walter, 2018). The loss of eelgrass beds has the potential to threaten the overall ecosystem health in and around Morro Bay. 


\subsection{Sample Collection}

To capture both the physical and biological drivers of the Morro Bay estuarine environment as well as understand how the eelgrass influences the water, it was crucial to take into consideration both spatial and temporal time scales when sampling.

\subsubsection{Transect Sampling}

To better understand the carbonate chemistry within the bay channel, transect sampling was carried out. Samples were collected from the mouth of the bay, P1, to the back bay, P10, (Figure 2.2) from the Center for Coastal Marine Sciences' (CCMS) vessel, the Munson. Transect samples were taken Early (June 28, 2018), Mid (August 9, 2018) and Late (September 7, 2018) Summer, with the objective of capturing the maximum differences each day, between high and low tide.

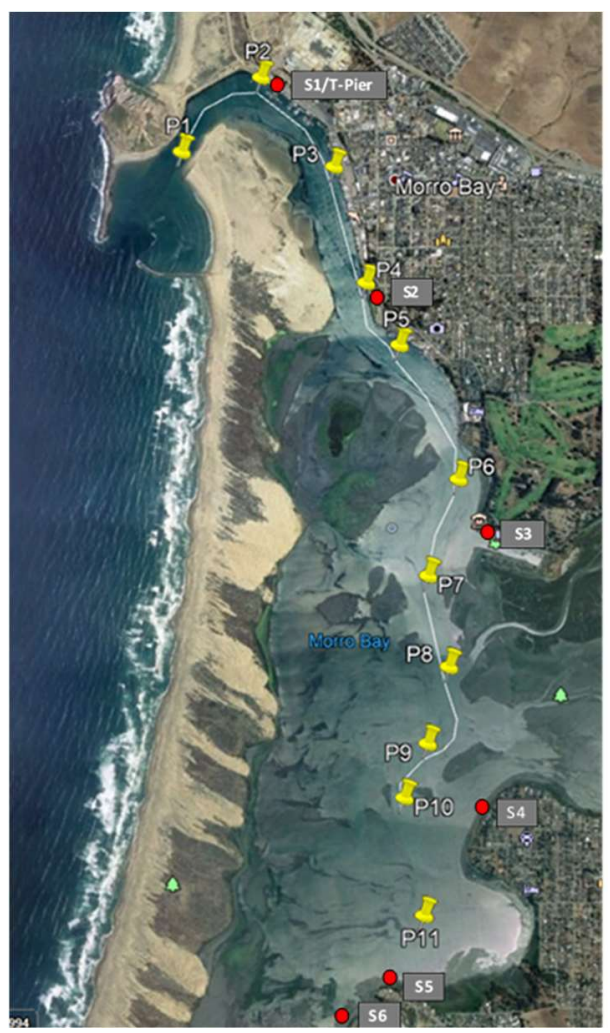

Figure 2. Location of the Ten Transect Stations Collected via a Boat (P1-P10) and the Six Shore Stations (S1-S6) During High and Low Tide in the Morro Bay Estuary. Yellow pins represent the GPS locations of the sampling points in the estuary. Red dots indicate the approximate shore locations. Figure modified from Sydney Werwerka and Google Maps. 
Since all sampling locations could not physically be sampled at the exact high or low tide time, samples were collected during their respective tide windows, beginning right before and completed after the tide change (Figure 2.3). Ten samples were collected during the high tide window in the morning, followed by ten more samples during the low tide window in the afternoon (Figure 2.3).

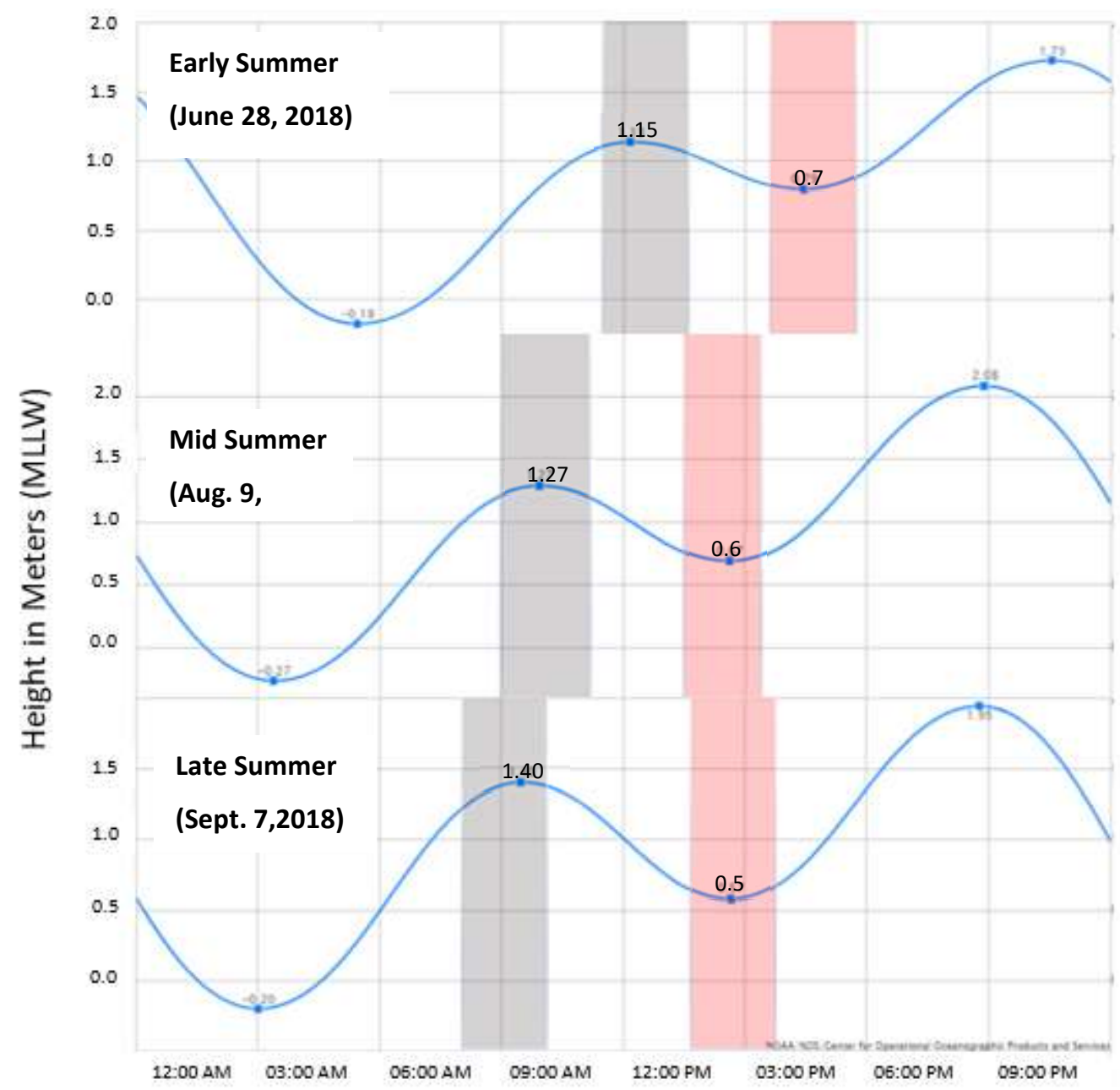

Figure 3. NOAA Tide Prediction Tables at Port San Luis CA. These were the closest tide table predictions to Morro Bay, from 12:00 am to 11:59 pm for transect samples during Early (top), Mid (middle) and Late Summer (bottom). MLLW is the mean lower low water depth, or the average of the lower low water height of each tidal day. Shaded boxes represent sampling time frame during high tide (grey) and low tide (red).

Discrete water samples were collected via a Niskin deployed 2 meters deep off the edge of a boat. Samples were collected in 500-mL borosilicate-glass bottles with greased ground-glass stoppers and preserved with $120 \mu \mathrm{L}$ of $\mathrm{HgCl}_{2}$ for storage, according to Dickson 2007 (Guide to 
Best Practices sampling techniques). To avoid changes in $\mathrm{CO}_{2}$ concentration caused by gas exchange during the transfer of the water from the Niskin to the glass bottle, each bottle was allowed to overflow with extra seawater from the Niskin. Sea-Bird Scientific 19+, that autonomously records Conductivity, Temperature, and Depth (CTD) was also deployed at each station. Preserved samples were transported back to Cal Poly's CCMS' lab for analysis.

\subsubsection{Shore Samples}

The seasonal fluctuations of the estuary was captured by sampling at regular locations throughout the bay from July to November. Six shore sampling stations (S1-S6) were chosen that span the spatial extent of the bay and provided reasonable accessibility from shore for sampling (Figure 2.2). These "shore samples" were collected once a week in the morning during the start of the high tide window, between 8:30 am and 11:00 am. Samples were collected in order that was opposite of the tide direction, to avoid continually sampling the same water mass as it moved into or out of the estuary. Each sampling point had varying depths, depending on the tide and therefore water samples were collected accordingly. All seawater samples were collected by hand via a one-meter Niskin from each shore location. S1-S3 samples were collected via a Niskin cast over the edge of a dock and submerged vertically in the water column. For S1 and S2, sample depth was 2 meters, while S3 samples were taken at the surface due to the shallow depth. For S4-S6 which had no docks, samples were collected by walking into the water to a depth of approximately 0.5 meters and submerging the Niskin horizontally just under the surface of the water. For all samples, the Niskin was submerged for a couple of minutes to allow for temperature equilibration, for any bubbles to escape, and to reduce the amount of sediment in the water column due to disturbance by the sampler. Samples were collected and stored using the same method as that of the transect samples (P1-P10) and then were transported back to the CCMS lab for analysis. Temperature and salinity data were measured in-situ using a YSI 2030 Water Quality probe (YSI probe) at locations S2-S6. The location of Station 1 at the Coast Guard's T-Pier allowed for us to use salinity and temperature data collected by the Central and 
Northern California Ocean Observing System (CeNCOOS) sensor located there. During the early Summer sampling days, the YSI probe was not available, and instead the data for S2-S6 was approximated using the average difference between each shore station during the late Summer months.

\subsection{Sample Analysis}

ALK, $\mathrm{pH}$ and DIC were determined for each sample. ALK was measured via open cell potentiometric acid titration using a custom instrument built to replicate the system designed by Andrew Dickson at Scripps Institution of Oceanography (Dickson, 2003). Seawater $\mathrm{pH}_{\mathrm{T}}$ was measured spectrophotometrically using $m$-cresol purple dye (Carter, 2015). Sample $\mathrm{pH}_{\mathrm{T}}$ was corrected to in-situ water temperatures using the $\mathrm{CO}_{2} \mathrm{Sys}$-v2.3 excel calculator to analyze the natural environment as accurately as possible. Dissociation constants were supplied by Lueker et al. (2000). DIC concentration was determined by acidifying a known volume of seawater sample and quantitatively determining the evolved $\mathrm{CO}_{2}$ using a non-dispersive infrared gas analyzer as described in Bockmon \& Dickson (2015).

\subsection{Quality Control}

All samples were corrected using a seawater Certified Reference Material (CRM) purchased for the SIO Dickson laboratory or a Sub-Reference Material (SRM) that was created internally at Cal Poly and characterized using a CRM. Research is ongoing to determine the uncertainty of the instruments. We conservatively estimate that both the DIC and ALK measurements have an uncertainty of $5 \mu \mathrm{mol} \mathrm{kg}^{-1}$ and $\mathrm{pH}$ has an approximate uncertainty of 0.01 . We also acknowledge that the ALK instrument is sensitive to large amounts of sediment due to the use of the electrode probe. $\mathrm{pH}$ measurements were also corrected for the perturbation caused by the $m$-cresol purple dye. 
The YSI probe was calibrated using a known and certified salinity standard and then adjusted to match the CENCOOS sensor at S1 to account for any discrepancies. There was also a lack of insitu probe data for the month of July thus having to rely on CENCOOS data. Final salinity data recorded using the $\mathrm{YSI}$ probe was adjusted by +2.4 and temperature was adjusted by $+0.4^{\circ} \mathrm{C}$ for all shore stations. Salinity data from S6 on September $26^{\text {th }}$ was removed from the data set given likely malfunction of the YSI probe.

We also recognize there could be bias in our water sampling technique. Sampling was collected against the tide direction, to avoid following the same water mass throughout the estuary. Most sampling started at S6, before the high tide ocean water had a chance to reach the back bay and could explain some of the observed carbonate chemistry variability. 


\section{RESULTS AND DISCUSSION}

Carbonate chemistry data are presented here for the transect and shore sampling days.

\subsection{Transect Analysis in the Bay Channel}

Spatial variability of the bay channel was captured from the bay mouth $(\mathrm{P} 1)$ to the back bay (P10) from the following transect samples. DIC and ALK increased while $\mathrm{pH}$ decreased towards the back bay and varied between tides.

\subsubsection{Physical Observations}

Physical oceanographic data for the transect samples was collected by Dr. Ryan Walter's Research Group with data analysis and interpretations performed by Sydney Wewerka, an undergraduate researcher. This data was crucial for understanding the physical changes in the estuary and providing context for interpreting the carbonate chemistry of the bay channel. Morro Bay is characterized as an inverted estuary during the low-inflow Summer season. The salinity increases towards the back bay during high and low tide (Figure 3.1).
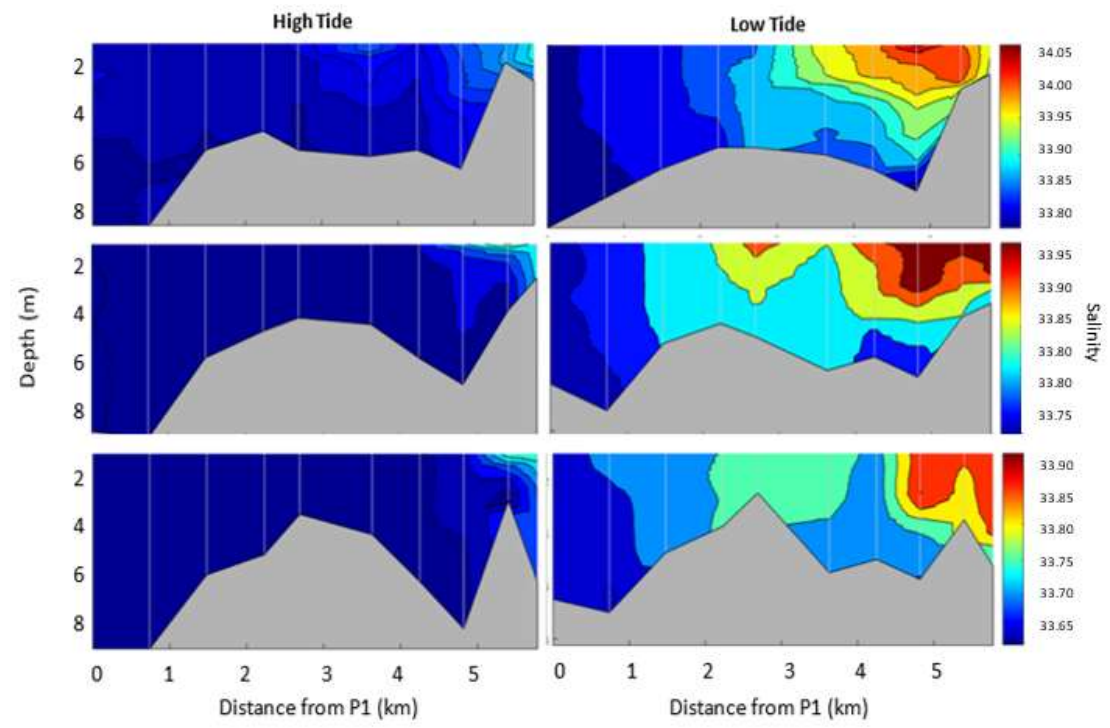

Figure 4. Salinity Profiles of Transect Samples Taken from the CTD Casts. Transects were sampled at both high (left) and low tide (right) during Early (top), Mid (middle) and Late Summer (bottom). Discrete water samples were taken at 2 meters. 
Water temperatures in the estuary are influenced by the local weather and by tidal changes.

Morro Bay is characterized by its morning sea fog and marine layer. The afternoon high tide air temperatures were $19.8^{\circ} \mathrm{C}$ (Early), $20.4^{\circ} \mathrm{C}$ (Mid), and $21.2^{\circ} \mathrm{C}$ (Late), while the morning low tide air temperatures were $12^{\circ} \mathrm{C}, 13.2^{\circ} \mathrm{C}$ and $12.9^{\circ} \mathrm{C}$, respectively (US Climate Data, 2019). At both high and low tide, water temperatures increase towards the back bay (Figure 3.2).
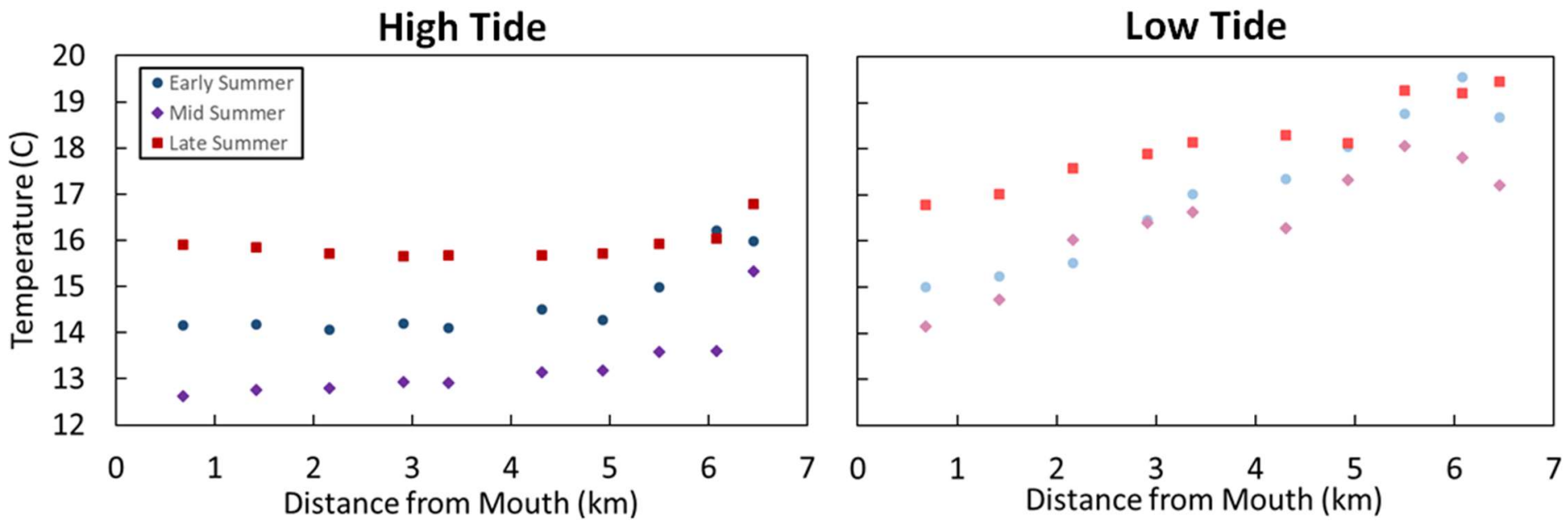

Figure 5. Temperature versus Distance from the Mouth Station (P1) at Both High and Low Tide During Early, Mid, and Late Summer.

Water temperatures are the highest in the back bay during low tide due to decreasing water depths. Mid Summer exhibited the lowest water temperatures for both high and low tide, even though it did not have the lowest overall air temperatures. On average, water temperatures increased from high to low tide. We observed a $2.4^{\circ} \mathrm{C}$ increase at $\mathrm{P} 1$ and $1.1{ }^{\circ} \mathrm{C}$ at $\mathrm{P} 10$ between high and low tide. High tide temperatures are controlled by the oceanic end member while low tide temperatures are more influenced by ambient air temperature. 


\subsubsection{Spatial Observations within the Bay Channel}

Water in the back bay is the shallowest thus ALK and DIC both increase towards the back bay during low and high tide (Figure 3.3). As DIC increases, $\mathrm{pH}$ decreases towards the back bay, as expected, given that $\mathrm{CO}_{2}$ behaves as an acid in seawater.

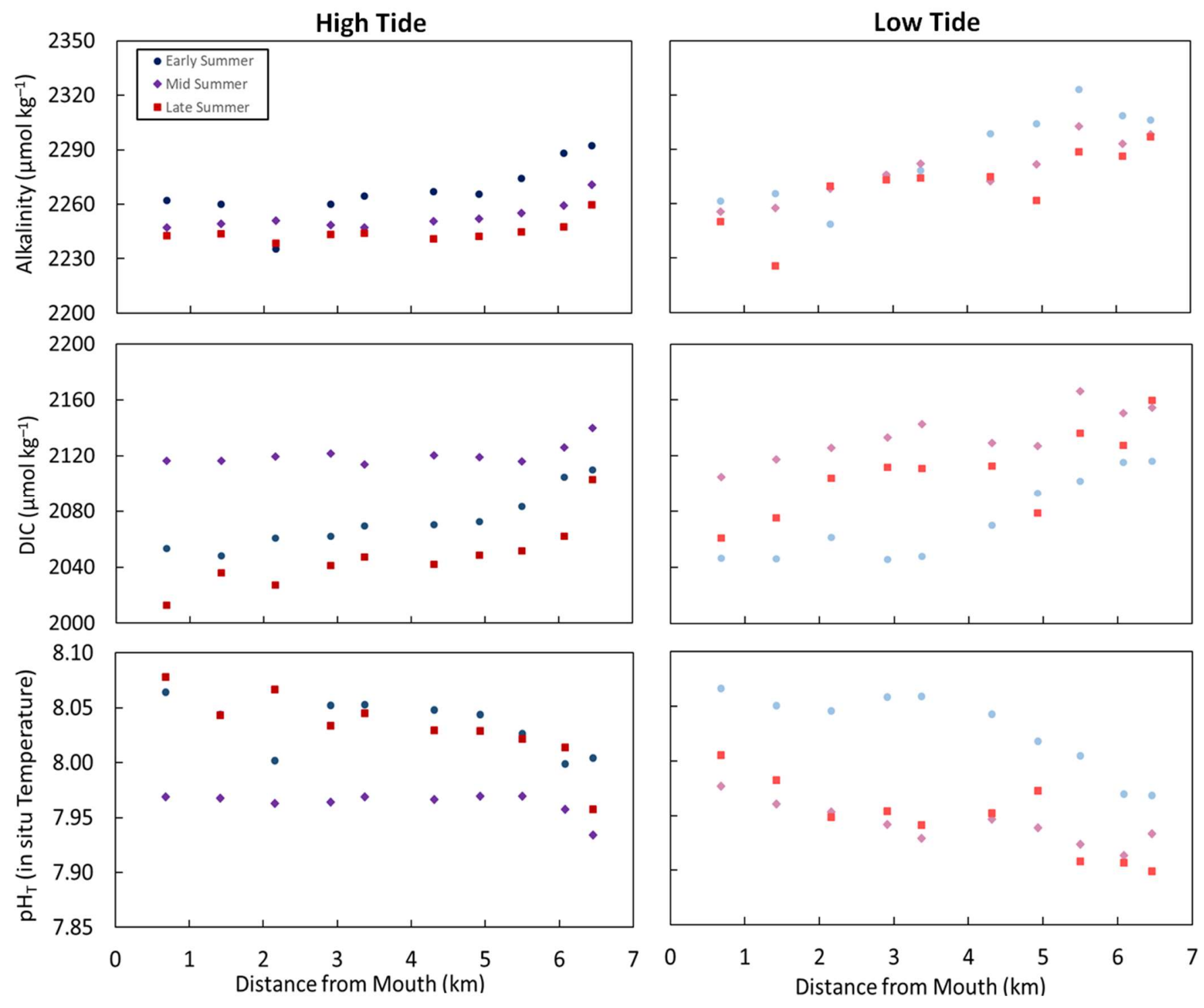

Figure 6. Alkalinity (ALK), Dissolved Inorganic Carbon (DIC) and In-Situ pH Measurements in Relation to the Distance from the Mouth at both High and Low Tide during Early, Mid and Late Summer. 
The estuary exhibited the highest DIC and lowest $\mathrm{pH}$ during the Mid Summer sampling day, at both high and low tide (Figure 3.3), indicating a difference in source waters coming from the California Current or biological processes occurring outside the bay, compared to the other sampling days. In contrast, ALK at the mouth of the bay was relatively constant throughout the summer.

The lowest water temperatures and $\mathrm{pH}$ were observed in Mid Summer while the highest water temperature and $\mathrm{pH}$ were observed in Late Summer (Figure $3.2 \& 3.3$ ). This goes against the expectation based on chemistry as $\mathrm{CO}_{2}$ gas is more soluble in colder waters, so the same amount of $\mathrm{CO}_{2}$ results in a higher $\mathrm{pH}$. Although $\mathrm{pH}$ is temperature dependent, temperature does not account for the differences in $\mathrm{pH}$ observed during the different sampling months, further indicating that other $\mathrm{CO}_{2}$ inputs are contributing to the lower $\mathrm{pH}$ observed during Mid Summer.

Greater variability was observed during low tide compared to high tide for all measured carbonate chemistry parameters (Figure 3.3). DIC and ALK appear to be more consistent with respect to sampling location during high tide compared to low tide, indicating the chemistry during high tide is primarily driven by tidal flushing from the ocean. During high tide, the average difference between the bay mouth station and the farthest back bay location was $23.6 \mu \mathrm{mol} \mathrm{kg}^{-1}$ and 56.6 $\mu \mathrm{mol} \mathrm{kg}{ }^{-1}$ for ALK and DIC, respectively. In contrast, the average difference between P1 and P10 for ALK and DIC during low tide was $44.9 \mu \mathrm{mol} \mathrm{kg}^{-1}$ and $72.8 \mu \mathrm{mol} \mathrm{kg}{ }^{-1}$, respectively. The larger magnitude of change in the carbonate chemistry of the estuary during low tide measurements was likely driven by biological processes in the bay. Late Summer exhibited the largest difference in carbonate chemistry between high and low tide, possibly due to a larger tidal difference, $0.83 \mathrm{~m}$ (Figure 2.3). DIC on average increased by $60 \mu \mathrm{mol} \mathrm{kg}{ }^{-1}$ between high and low tide compared to the increase of $1.1 \mu \mathrm{mol} \mathrm{kg}{ }^{-1}$ and $14.3 \mu \mathrm{mol} \mathrm{kg}^{-1}$ for Early and Mid Summer, respectively. This could be due to the different source ocean water bringing in elevated DIC during Late 


\subsubsection{Hydrodynamic Controls}

The carbonate chemistry of Morro Bay is likely influenced and amplified by various hydrodynamic processes within the estuary. ALK and salinity change throughout the Summer season and vary between tides. As expected, ALK increases with increasing salinity at both high and low tide (Figure 3.4).
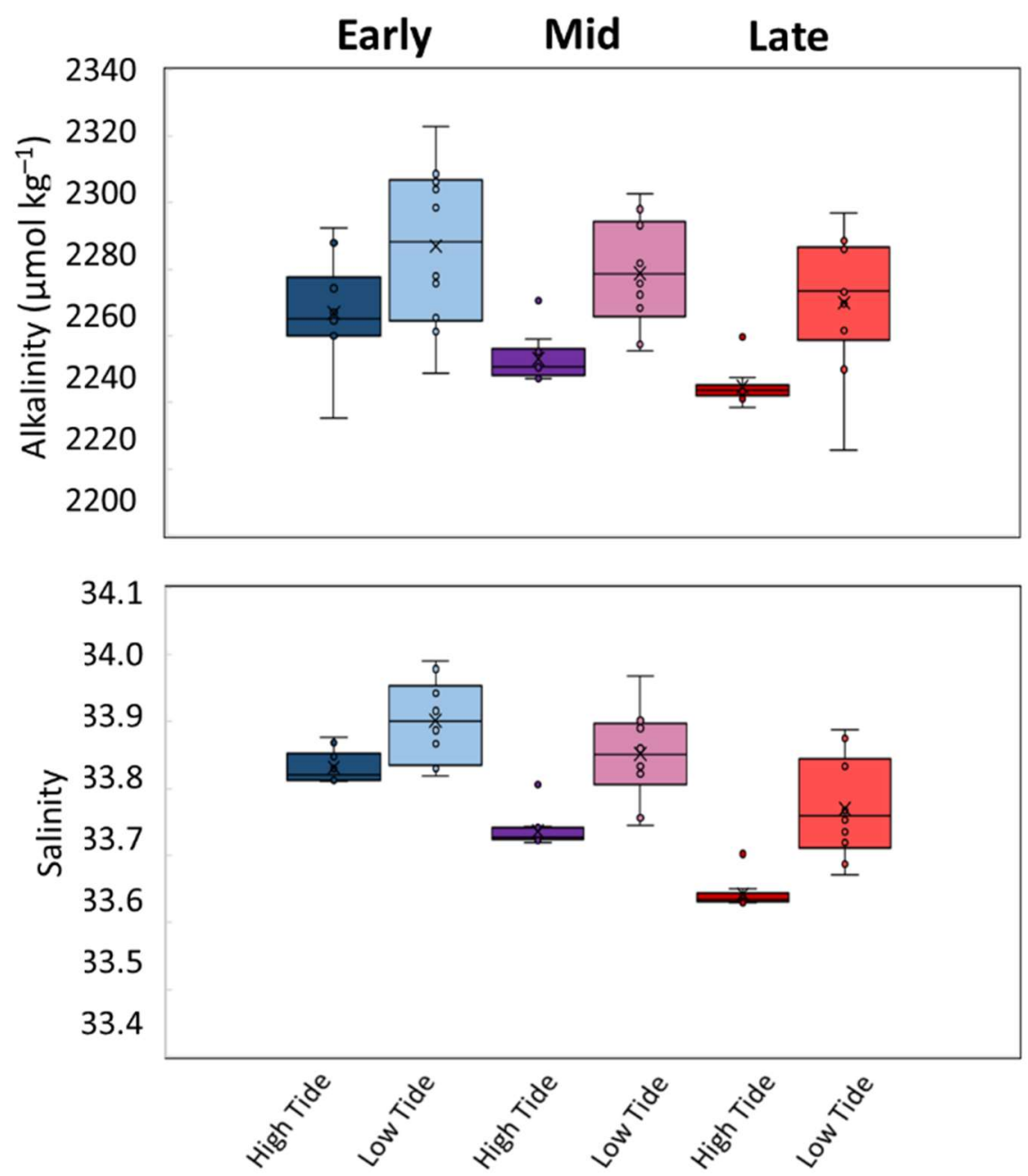

Figure 7. ALK (Top) and Salinity (Bottom) for Early, Mid and Late Summer at High and Low Tide.

There is an overall decrease in salinity across the Summer season. Early Summer had the highest salinity and ALK while Late Summer had the lowest (Figure 3.4). Differences in salinity and ALK at high tide, particularly near the mouth of the bay, indicate differences in the chemistry of the source water entering the bay from the ocean throughout the season. 
There was an increase in salinity and ALK, and an increase in variability of these parameters at low tide compared to high tide (Figure 3.4). The average increase from high to low tide were 0.07 , 0.11. and 0.13 for Early, Mid and Late Summer, respectively. The back bay exhibited higher salinity values and varied with the tides. Early Summer at high tide had a 0.05 salinity change from $\mathrm{P} 1$ to $\mathrm{P} 10$ compared to a 0.12 salinity change during low tide. Late Summer at high tide had a salinity range of 0.07 compared to 0.22 during low tide. Mid Summer salinities fell between Early and Late Summer. The increase in salinity during low tide is likely driven by evaporation in the shallow back bay waters as air temperatures increase into the afternoon. The salinity ranges also increase throughout the Summer season, as air temperatures increase. ALK is a conservative parameter and increases proportionally with salinity. As the high tide recedes, the newly modified water from the back bay flushes towards the mouth causing increased ALK and salinity and increased variability throughout the bay during low tide. 


\subsubsection{Influences of Biological Processes}

Alongside the physical processes happening within the estuary, biological processes also can influence carbonate chemistry. The possible biological effects primarily are DIC changes from photosynthesis and respiration processes and DIC and ALK changes from calcification and dissolution of shells. To highlight the role of biological modifications within the bay, DIC and ALK were both normalized to a salinity of 34 to remove the role of physical processes, such as evaporation and mixing. This way we can see the potential influence of biological modifications to the carbonate chemistry. At both high and low tide, there is an expected inverse relationship between $\mathrm{nDIC}$ and $\mathrm{pH}$ and a general increase in variability during low tide (Figure 3.5).
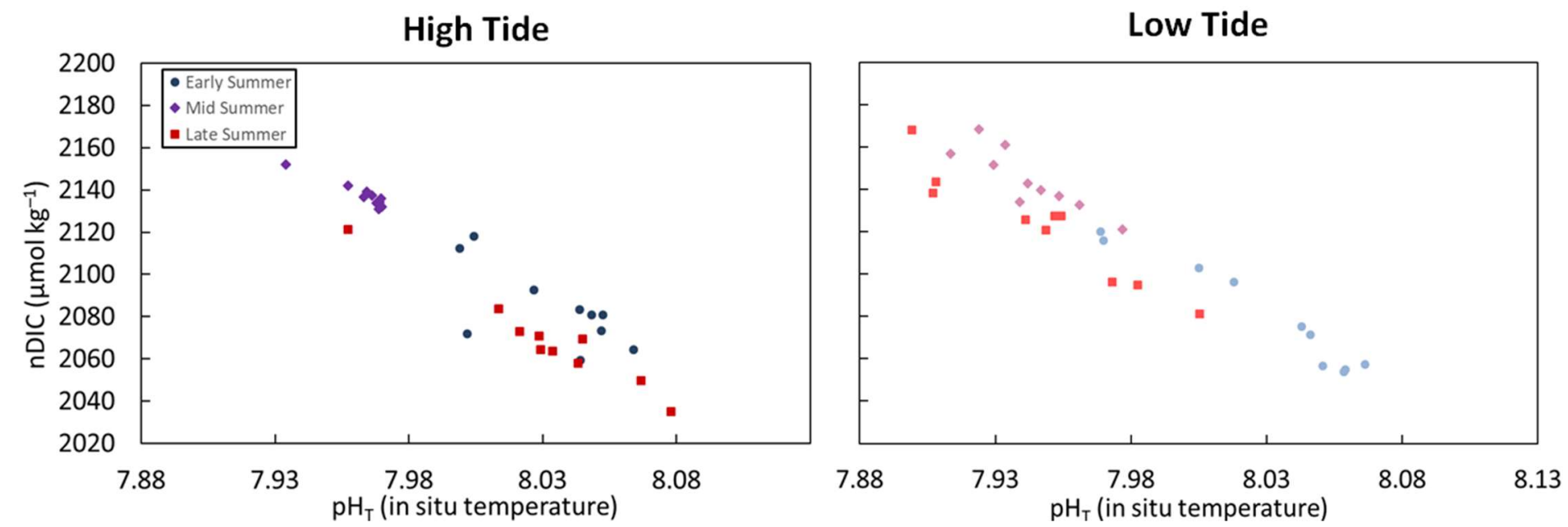

Figure 8. DIC Normalized ( $\mathrm{nDIC}$ ) to the Oceanic End-Member Salinity of 34 versus pH Corrected for In-Situ Temperatures at High and Low Tide during Early, Mid and Late Summer.

During Late Summer, $\mathrm{nDIC}$ and $\mathrm{pH}$ change substantially between high and low tide (Table 2.1). Although the range of values increases at low tide during Early and Mid Summer, the average values stay approximately the same, indicating only a small increase in $\mathrm{CO}_{2}$ at low tides. Late Summer had the lowest tide out of all the transect sample days in which we could expect increased primary production and corresponding pH compared to high tide (Cryonak et al.,2018). We observed a general decrease in $\mathrm{pH}$ during low tide, indicating increased respiration rates during Late Summer. 
Table 1. Differences Between High and Low tide for nDIC and $\mathrm{pH}$ Averages

\begin{tabular}{|c|c|c|}
\hline & $\begin{array}{c}\boldsymbol{\Delta} \mathbf{~ n D I C} \\
\left(\mu \mathrm{mol} \mathbf{~ k g}^{-1}\right)\end{array}$ & $\boldsymbol{\Delta} \mathbf{p H}$ \\
\hline Early & 3.2 & 0.005 \\
\hline Mid & 7.1 & 0.021 \\
\hline Late & 54.1 & 0.088 \\
\hline
\end{tabular}

ALK in Morro Bay is not only influenced by salinity, but also driven by biological modifications such as dissolution of $\mathrm{CaCO}_{3}$. An increase in $\mathrm{ALK}$ can be indirectly attributed to a decrease in DIC from photosynthesis and carbon burial. To further highlight the differences in ALK due to biological processes in the bay, the contribution of ALK from the source water was removed by subtracting ALK at P1 from all samples (Figure 3.6).

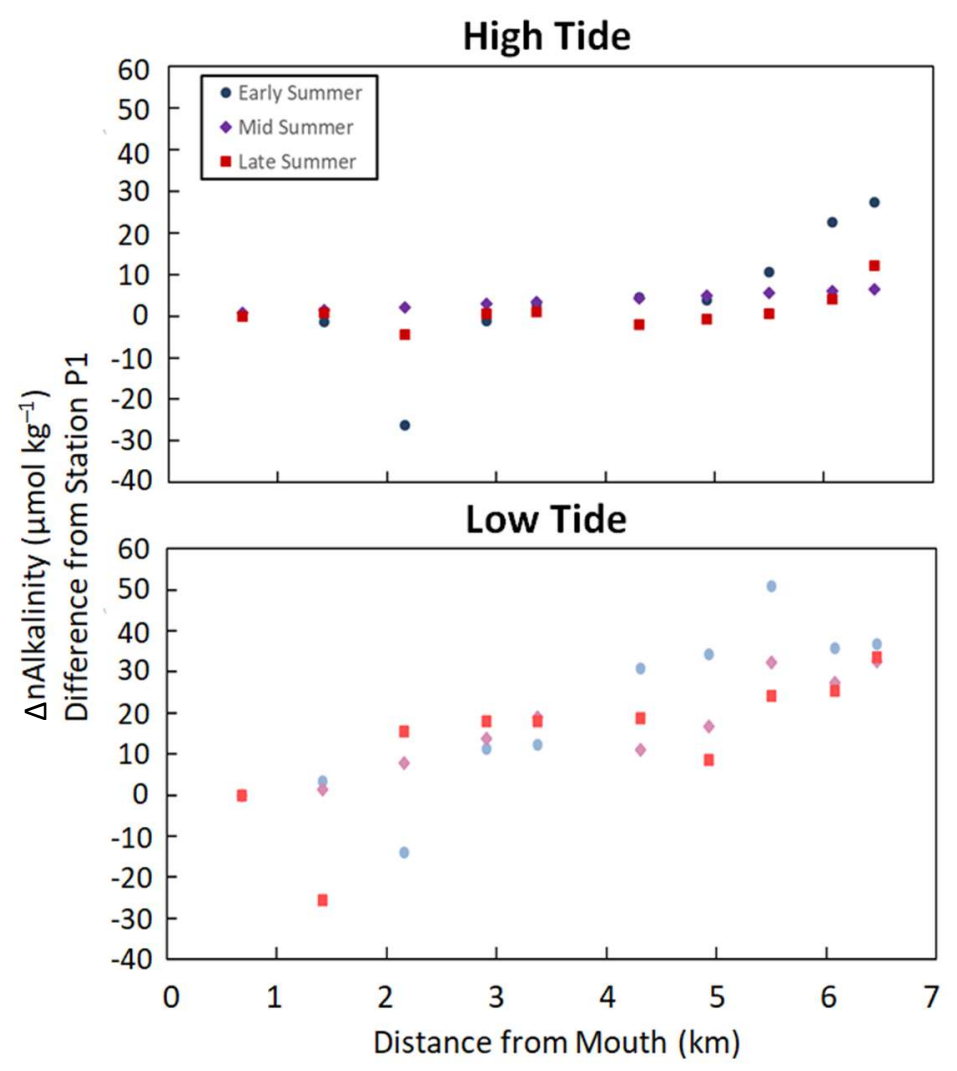

Figure 9. Contribution of Biological Modifications to Alkalinity (nALK) at High and Low Tide in Relation to the Distance from the Bay Mouth during Early, Mid and Late Summer. Alkalinity was normalized to an average ocean salinity of 34 to remove the role of evaporation. Mixing from the open ocean was removed by subtracting the alkalinity at P1 from each measurement. 
At both high and low tide, there is an increase in nALK towards the back bay, with larger differences at low tide (Figure 3.6). nALK is constant from the bay mouth to approximately $5 \mathrm{~km}$ into the estuary, as water enters the bay from the adjacent ocean. Between 5 and $6 \mathrm{~km}$, or P8P10, nALK starts to increase, as either photosynthesis decreases DIC or dissolution increases the alkalinity in the water. These stations are located in the back bay where water depths are very shallow and where much of the seafloor is covered in a fine mud potentially taking in DIC. This increase of alkalinity in the back bay leads us to believe that there may be a significant contribution to water column chemistry from processes occurring in the mud. During low tide, the effect of the modification of the water column chemistry is amplified due to low water volume. nALK increases up to $50 \mu \mathrm{mol} \mathrm{kg}{ }^{-1}$ above the seawater end-member, a substantial contribution to the back bay waters.

Between 1 and $2 \mathrm{~km}$, negative $\triangle \mathrm{nALK}$ values were observed indicating the bay mouth station had greater ALK. These sampling locations have active marine life and boat activity, which could have caused an increase in DIC and contributed to the lower ALK. These samples could also be negative due to possible analysis error. 
At both high and low tide, observed variability was in carbonate chemistry beyond gas exchange. Possible variations include influences from calcification and dissolution of shelled organisms as well as photosynthesis and respiration rates (Figure 3.7).

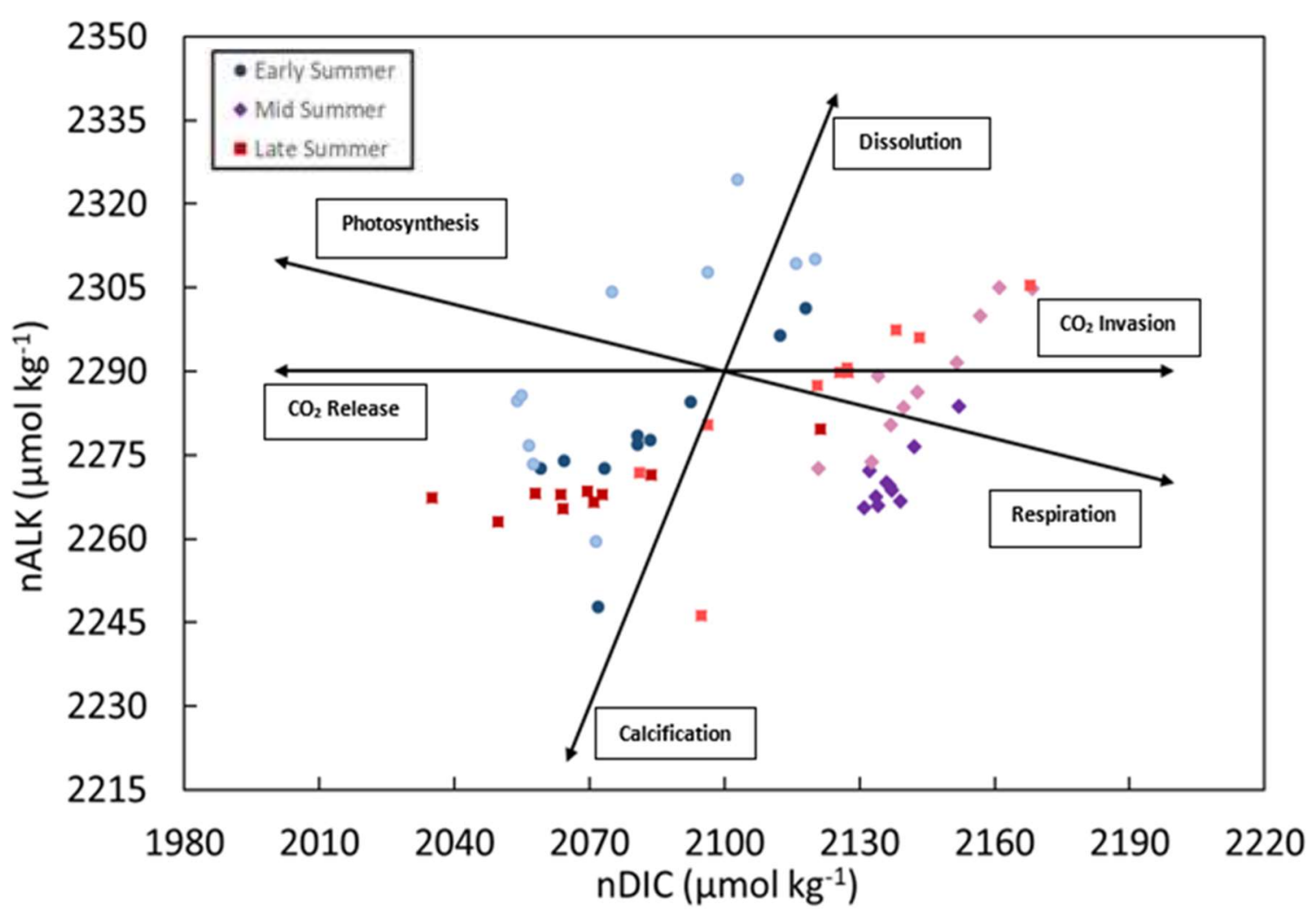

Figure 10. Normalized Dissolved Inorganic Carbon (nDIC) versus Normalized Alkalinity (nALK) for Early, Mid and Late Summer at High and Low Tide. Dissolution and calcification of calcium carbonate $\left(\mathrm{CaCO}_{3}\right)$ is represented by calcification and dissolution. Organism metabolic processes are represented by respiration and photosynthesis arrows. Gas exchange is represented by $\mathrm{CO}_{2}$ release into the atmosphere and $\mathrm{CO}_{2}$ invasion as dissolution into the ocean. $\mathrm{nDIC}$ and $\mathrm{nALK}$ were normalized to a salinity of $34 \mathrm{ppt}$ to remove differences caused by changes in salinity.

Early Summer at high tide is primarily influenced by dissolution and calcification, with influences from gas exchange further lowering the $\mathrm{nDIC}$. Early Summer at low tide shifts towards a photosynthesis signal, with decreasing nALK and nDIC. Low water depths facilitate increased rates of photosynthesis due to increased sunlight availability. Mid Summer, for both high and low tide, primarily exhibits a dissolution and calcification signal. During low tide, it shifts further towards dissolution, with increasing nALK. It is unclear why this is observed during Mid Summer, but as previously stated it could be attributed to carbon burial in the mud towards the back bay. 
Late Summer values also follow a dissolution and calcification signal, but with large influences from gas exchange. During low tide, $\mathrm{nDIC}$ and $\mathrm{nALK}$ increase, indicating gas exchange and dissolution occurring simultaneously. Our current models do not indicate that $\mathrm{CO}_{2}$ invasion is occurring due to the high $\mathrm{pCO}_{2}$ values observed in the water. This further displays how the change in seasons and various inputs into the estuary are influencing the carbonate chemistry. 


\subsection{Shore Water Sample Analysis}

Results from analysis of samples taken from our six shore locations show increased variability in carbonate chemistry between the back and front bay compared to transect samples.

\subsubsection{Salinity and Temperature in the Front and Back Bay}

Generally, we observed a slight decrease in salinity towards the back bay during Fall shore sampling, in contrast to the increasing salinity observed in the back bay during the Summer transects (Figure 3.8).
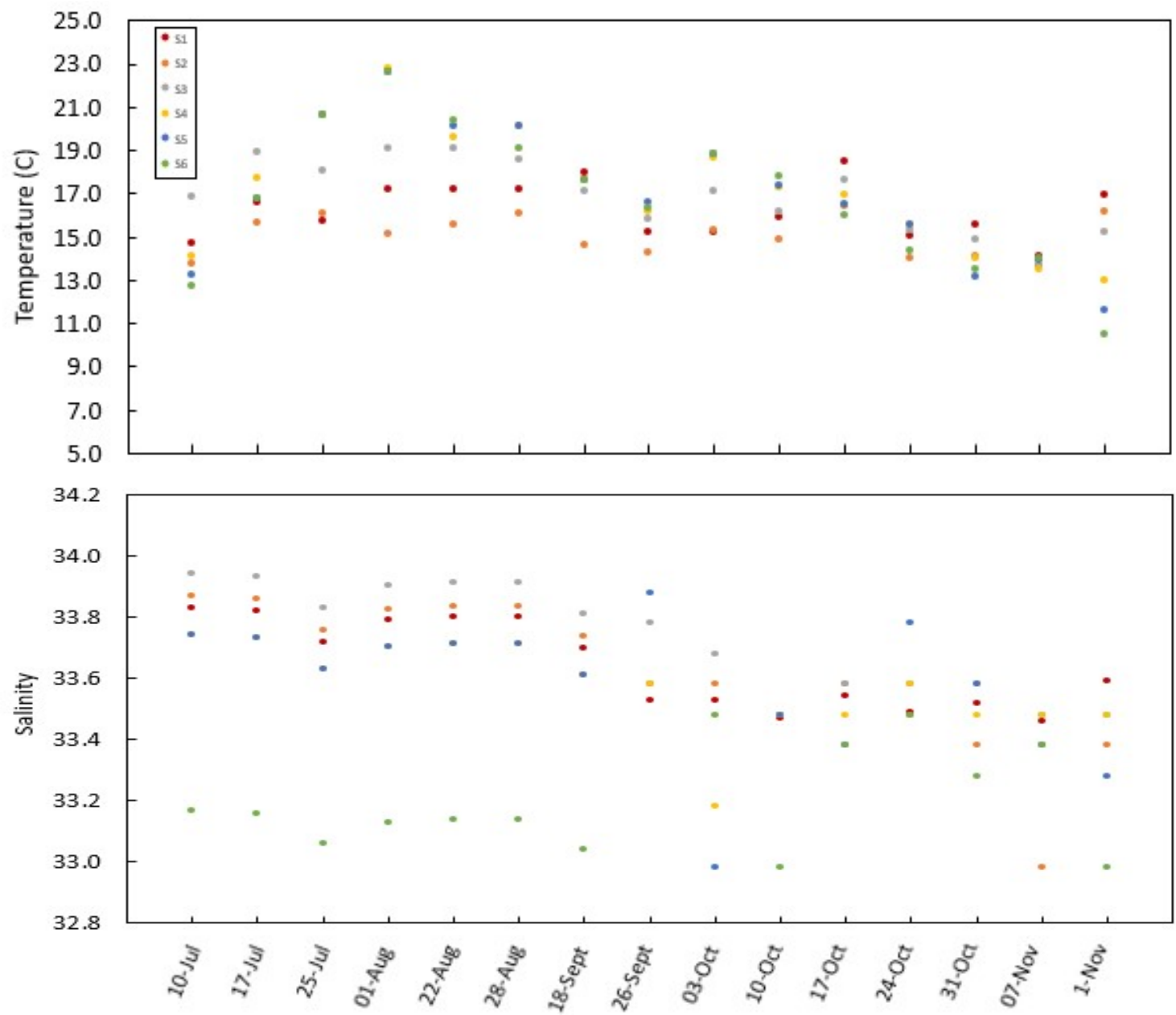

Figure 11. Temperature (Top) and Salinity (Bottom) for Shore Stations (S1-S6) Over the Season (July through November). In situ YSI probe data was calibrated against CENCOOS TPier data. It is important to note that all the data was not collected with a YSI probe, especially during the summer season. Average differences between stations were used to estimate the beginning summer station. The sample point at S6 during September 26 was removed due to malfunction of the YSI probe. 
The back bay had the highest average water temperatures during the months of July and August and then decreased from September through November, with November having the lowest average water temperature. The average water temperature in August was $19.03^{\circ} \mathrm{C}$ and November had an average water temperature of $13.86^{\circ} \mathrm{C}$. This correlates with decreasing air temperatures. Average air temperatures during August ranged from a high of $20.6^{\circ} \mathrm{C}$ and a low of $13.3^{\circ} \mathrm{C}$ and average air temperatures during November ranged from $20.6^{\circ} \mathrm{C}$ to $9.4^{\circ} \mathrm{C}$ (US Climate Data, 2019). From October $17^{\text {th }}$ to November $14^{\text {th }}$, water temperatures in the back bay fell below the front bay stations. August had an average water temperature of $20.70^{\circ} \mathrm{C}$ in the back bay while November had an average of $12.25^{\circ} \mathrm{C}$. Many of the of the back bay stations were sampled during the later part of the morning, which could contribute to the temperature variability.

The back bay often had the lowest salinity while the front bay had the highest salinities, an overall 0.5 salinity decrease from the front to back bay. Lower salinity in the back bay is likely due to increased freshwater input from Los Osos and Chorro Creeks and is typical of many estuarine environments. The observed decrease in salinity could be magnified by the choices about sampling timing mentioned earlier. Salinity also decreases as the season progresses; July had an average of 33.68 while November had an average of 33.36 . This seasonal variability is due to cooler air temperatures during the Fall months causing less evaporation and increased freshwater input from the two creeks. 


\subsubsection{Carbonate Chemistry in the Front and Back Bay}

We observed distinct differences between the front and back bay for both ALK and DIC (Figure 3.9). ALK increased an average of $150 \mu \mathrm{mol} \mathrm{kg}{ }^{-1}$ between $\mathrm{S} 1$ and $\mathrm{S} 6$ and increased $80 \mu \mathrm{mol} \mathrm{kg}^{-1}$ from S3 to S4. We observed a $171.1 \mu \mathrm{mol} \mathrm{kg}^{-1}$ increase in DIC between S1 and S6 and a 71.2 $\mu \mathrm{mol} \mathrm{kg}{ }^{-1}$ increase from S3 to S4.
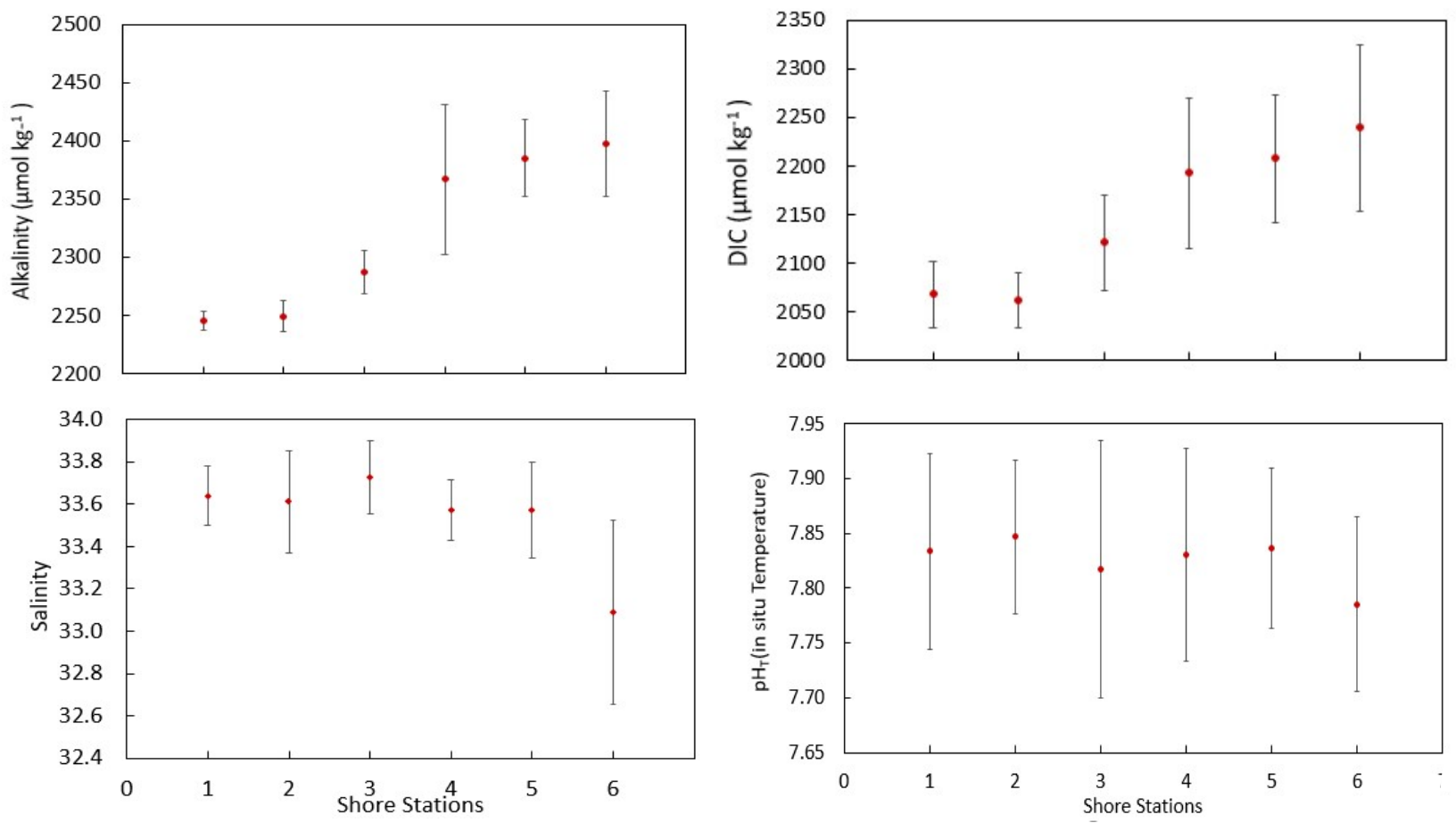

Figure 12. Average ALK and DIC (Top) and Salinity and $\mathrm{pH}_{\mathrm{T}}$ (Bottom) for July through November Sampling Days with Error Bars Representing the Standard Deviation.

The distinct difference between the front and back bay is expected from the low tidal flushing and high residence time that has been observed in the estuary (Walter, 2018). The front bay shows low variability in ALK and DIC compared to the back bay, indicating little modification in the bay and likely tracking similarly to the oceanic endmember. We observed the highest levels of suspended sediment and mud at S5 and S6 out of all the stations. The increase of both ALK and DIC towards the back bay are likely contributed to by biological processes in the sediment and dissolution processes. 
To confirm that the increased sediment at S4-S6 did not cause this effect, experiments were performed to measure the difference between filtered and unfiltered seawater samples.

Preliminary tests found an approximate $20 \mu \mathrm{mol} \mathrm{kg}{ }^{-1}$ increase in DIC when analyzing unfiltered samples. This could contribute to,but cannot fully explain the observed increase in DIC towards the back bay. More experimentation is underway to further confirm this discrepancy, and to expand the results to include ALK modification.

During the Fall in Morro Bay, we did not observe the expected positive relationship between ALK and salinity for seawater. ALK increases despite decreasing salinity towards the back bay (Figure 3.9). It is also interesting that $S 4$ has the largest variability in ALK but did not exhibit the largest variation in salinity. This further shows how physical drivers, such as salinity change driven by tides, is not the most important driver of variability in carbonate chemistry within the estuary, especially near the shore.

On average there was no difference in $\mathrm{pH}$ between stations, however we did observe a slight decrease in $\mathrm{pH}$ at S6, corresponding to the observed increases in DIC. There was an observed decrease in $\mathrm{pH}$ on one sampling day (August $22^{\text {nd }}$ ) correlating to the increase in DIC that was also observed. There was not an apparent increase or decrease throughout the season. We hypothesize this could be due to unknown inputs into the water, other than DIC, causing the variability in acidity. Further analysis is needed to understand the variations, no further conclusions can currently be made for $\mathrm{pH}$. Similar to the observations from the transect samples (Figure 3.6), there was an increase in nALK towards the back bay (Figure 3.10). Compared to the transect samples, we observe increased ALK and DIC at the corresponding shore stations. Average August ALK at S6 was approximately $94 \mu \mathrm{mol} \mathrm{kg}^{-1}$ higher than the low tide ALK during the August (Mid Summer) transect sampling day; DIC was approximately $47 \mu \mathrm{mol} \mathrm{kg}{ }^{-1}$ higher. With the exception of S6, pH generally decreases towards the back bay as expected with increasing DIC, although there is not a strong trend (Figure 3.9). 


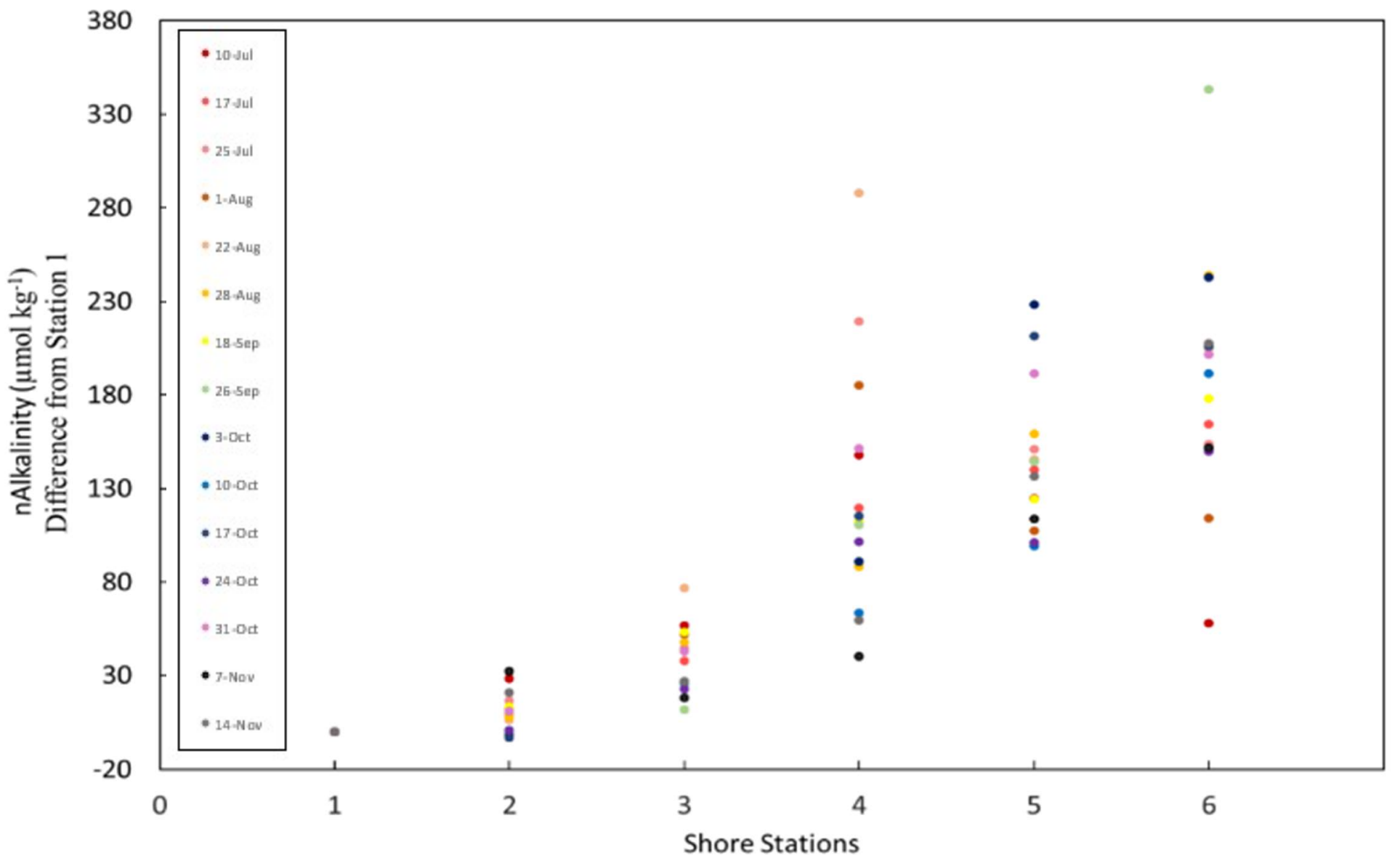

Figure 13. nAlkalinity During the Shore Sampling Days Relative to the Shore Stations within the Bay. Alkalinity was normalized to an average ocean salinity of 34 to remove the role of evaporation. Mixing from the open ocean was removed by subtracting the alkalinity at Station 1 from the alkalinity at each station.

Shore samples display a higher nALK difference compared to the transect samples. Transect samples had nALK up to $50 \mu \mathrm{mol} \mathrm{kg}{ }^{-1}$ while shore nALK increased up to $300 \mu \mathrm{mol} \mathrm{kg}^{-1}$. As observed previously, the front bay locations show the least variation compared to the back bay. Much of the loss of eelgrass was in the back bay, which could contribute to the observed increase in ALK and DIC through high respiration rates and dissolution. There is an average nALK increase of 180 units from $\mathrm{S} 1$ to $\mathrm{S} 6$, showing the possibility of strong biological modifications in the back bay. 


\subsubsection{Seasonal Changes in Carbonate Chemistry}

On average, ALK decreased throughout the season at the front bay and increases towards the back bay (Figure 3.11). The highest ALK was observed at S4 during the July $25^{\text {th }}$ and August $22^{\text {nd }}$ sampling days, $59 \mu \mathrm{mol} \mathrm{kg}{ }^{-1}$ and $100 \mu \mathrm{mol} \mathrm{kg}{ }^{-1}$ higher, respectively, than the monthly average.
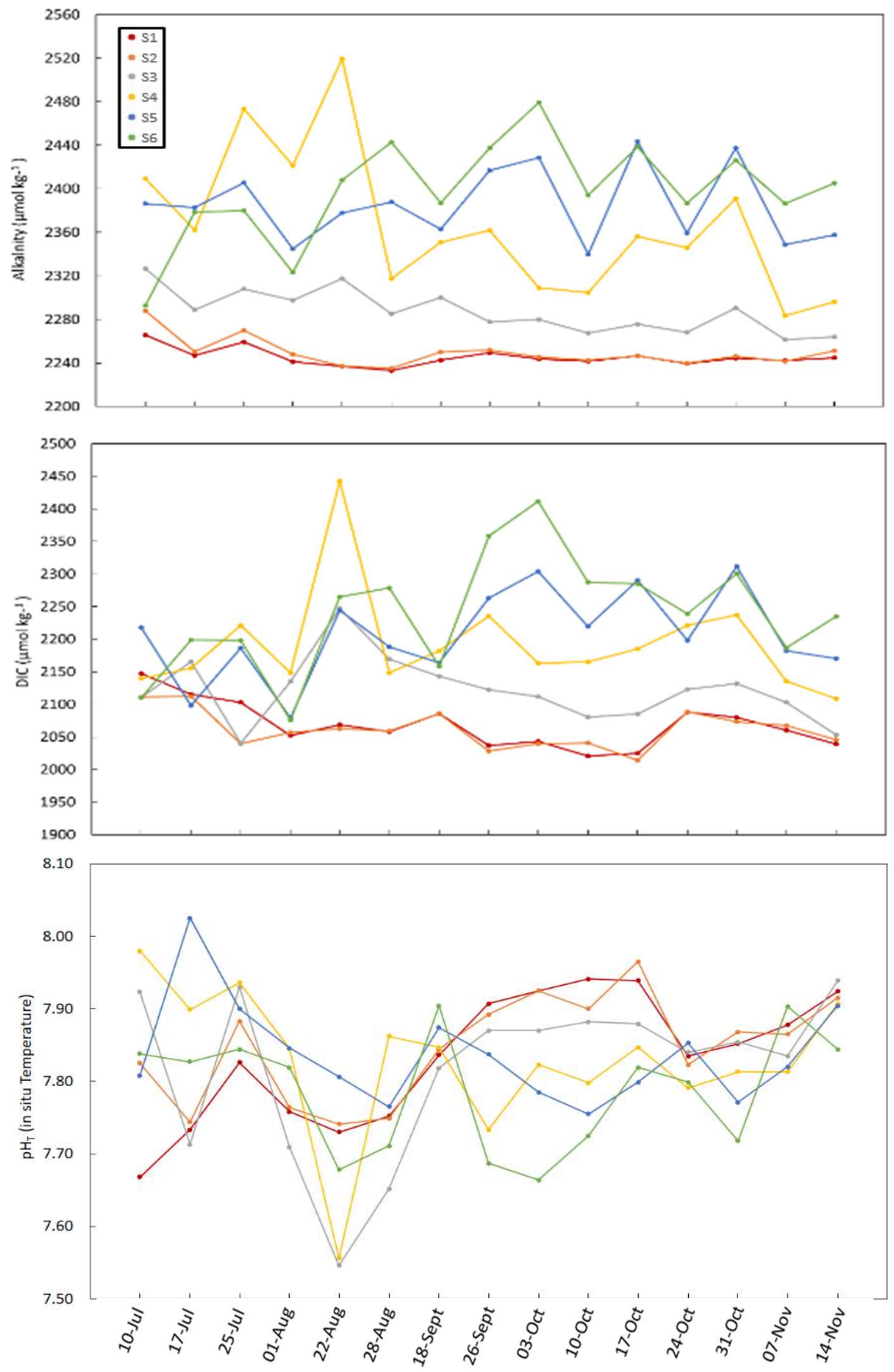

Figure 14. ALK, DIC and In-Situ pH versus the Sampling Dates (July through November) for Each Shore Station (S1-S6). 
We speculate that the high value during July $25^{\text {th }}$ is due to an error in sample analysis. For the data collected August $22^{\text {nd }}$, the high ALK corresponds with an increase in DIC and decrease in $\mathrm{pH}$, increasing confidence that the observed increase is real. ALK, on average, is highest during the July through September months from S1- S4. At S5, the average October ALK starts to increase. It is important to note that October was the most heavily sampled month, five samples were taken during this month at each location. At S6, October $3^{\text {rd }}$ had the highest ALK and DIC, and the second highest overall, despite the fact that it was raining. The effect of fresh water would be to decrease ALK and DIC, so we hypothesize that the observed increase is due torunoff from the streets as well as runoff over rocks and sediment.

We also observed a decrease of variability in DIC throughout the season. S1-S3 showed an overall DIC decrease throughout the season while S4-S6 showed an overall increase. From October to November, DIC variability at the front bay decreases; October $3^{\text {rd }}$ had a DIC range of $68.28 \mu \mathrm{mol} \mathrm{kg}{ }^{-1}$ and November $14^{\text {th }}$ had a range of $14.27 \mu \mathrm{mol} \mathrm{kg}{ }^{-1}$. This decrease in seasonal variability is likely due to decreased respiration rates during the cooler Fall months. 


\section{CONCLUSIONS}

The effects of climate change are complex in a small estuarine environment like Morro Bay. The estuary has various physical and biological drivers that cause spatial and temporal differences throughout. The rapid decline of Z. marina beds is one indication that the estuary is being affected by outside influences such as ocean acidification and urbanization that are causing a shift in the carbonate chemistry.

\subsection{Processes that Affect Carbonate Chemistry in the Estuary}

We observed increased ALK and DIC with decreasing $\mathrm{pH}$ towards the back bay. ALK and DIC also increased at the shore stations compared to the transect stations, emphasizing spatial differences within the bay. As the season progressed from warmer summer months to cooler fall months, ALK and DIC decreased at the shore stations highlighting seasonal fluctuations within the bay.

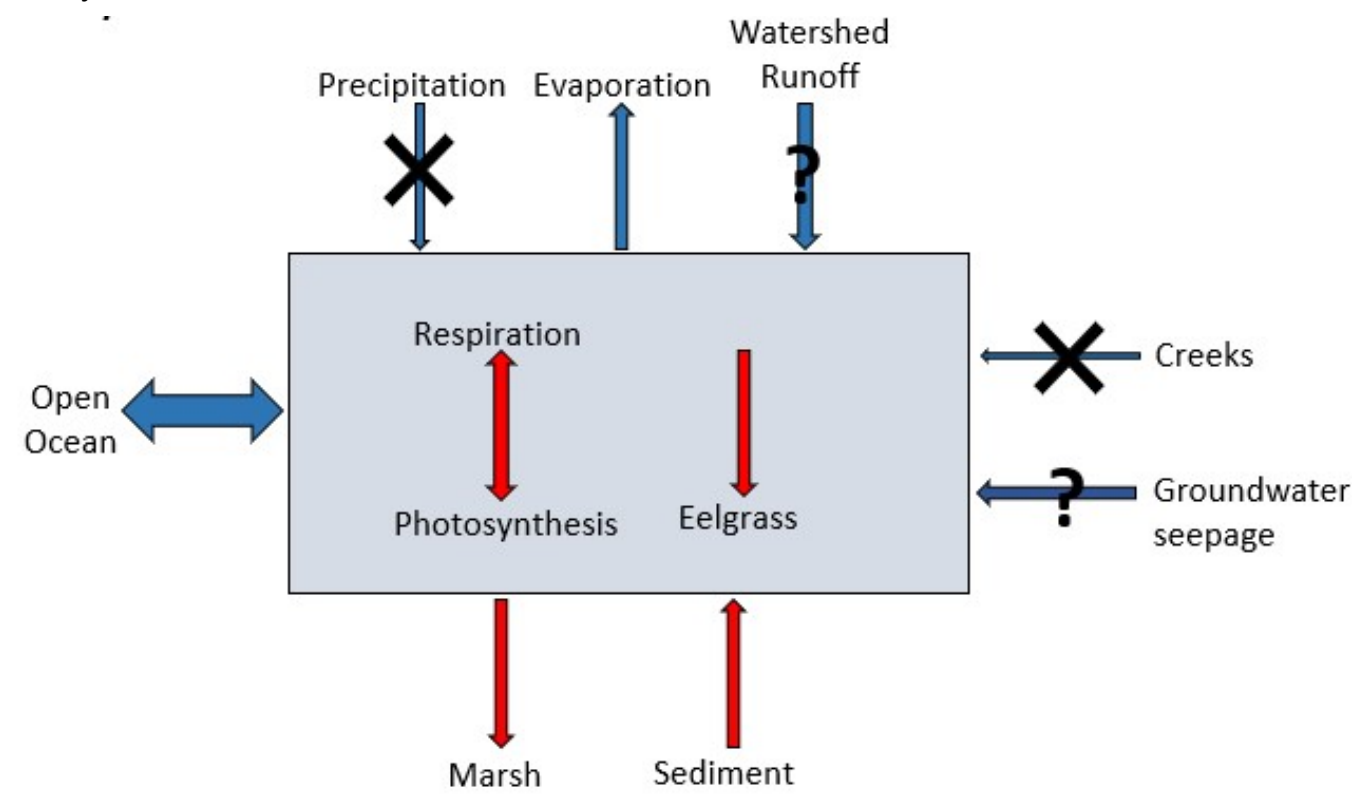

Figure 15. Simple Box-Model Displaying the Various Inputs into the Bay. Thickness of arrows represent the approximate input amount, with precipitation and creeks having the smallest contributions, and open ocean having the largest. Blue arrows indicate water inputs/outputs and red arrows indicate DIC inputs/outputs. The double arrow represents the exchange both into the estuary and out to the open ocean. DIC is commonly buried in marshes and transported in sediment. 
There are various inputs and outputs that differ both spatially and seasonally that could be influencing the overall carbonate chemistry in Morro Bay (Figure 4.1).

Because the carbonate chemistry fluctuated throughout the bay and throughout the season, gas exchange is likely not the only DIC source into the estuary. ALK and DIC both increased towards the back bay and increased towards the shore. Many of the observed inputs are attributed to biological processes happening within the estuary. Elevated DIC is likely due to increased respiration from marine life while primary production via eelgrass is expected to decrease DIC. On the contrary, dissolution of shelled organisms cause an increase in ALK. DIC and ALK also increase with increased biological inputs from sediment. Significant amounts of carbon also said to be buried in estuarine sediments and marshes, likely contributing to the increased ALK observed in the back bay (Bauer et al., 2013).

There are also physical drivers influencing the carbonate chemistry alongside the biological inputs into the estuary. It was also observed that low water depths, especially in transect samples, cause an increase in ALK due to evaporation effects which decreased throughout the season with cooler air temperatures. The bay experiences low freshwater inputs, with the least amount of precipitation occurring June through September and the rainiest season December through March (US Climate Data 2019). Due to low overall precipitation on land during the summer season, Los Osos and Chorro Creeks do not input substantial freshwater into the bay, causing an inverted estuary to occur within the bay channel. For both shore and transect samples, normalized ALK increased towards the back bay when evaporation and mixing contributions were accounted for. In both the shore and transect samples, carbonate chemistry fluctuated the least at the front bay, indicating that a significant amount of water exchange occurs at the mouth of the bay.

Lastly, there could also be inputs outside the estuary environment, such as groundwater seepage and surface runoff that contribute to the observed carbonate chemistry. It is currently unknown 
how much groundwater seepage is entering Morro Bay. Similar to what is observed in Mission Bay, transect ALK had a close relationship with tide and salinity change indicating that nonbiological processes, such as groundwater and surface runoff, might also play a large role in controlling the carbonate chemistry in the Summer months (Cyronak et al., 2017). Shore samples collected October $3^{\text {rd }}$ show how runoff from precipitation can potentially increase the ALK and DIC. ALK still increased in the back bay despite lower salinity water, indicating the potential presence of watershed runoff and groundwaters seepage into the estuary bringing acid-base species into the bay. The many inputs into and out of the bay further add to the complexity when pinpointing influences to carbonate chemistry beyond atmospheric $\mathrm{CO}_{2}$ absorption. 


\subsection{Effect of Estuarine Carbonate on the Global Carbon Cycle}

Due to climate and land use changes, it has been reported that there is a decrease in net carbon burial in estuary environments and thus estuaries act as a potential $\mathrm{CO}_{2}$ source into the adjacent ocean via the continental shelves (Bauer et al., 2013). Estuarine export of modified waters to the near-shore coastal environment could intensify or lessen the impact of ocean acidification with the potential to impact the coastal environment (Paulsen et al., 2017). Estimates of DIC and organic carbon export from estuaries range from 2.5 to $361 \mathrm{~mol} \mathrm{C} \mathrm{m}^{-2}$ year-2 (Paulsen et al., 2017; Cai et al., 2003; Ortega et al., 2005). Morro Bay's dynamic carbonate chemistry is not only having a localized impact to the ecosystem but also has the potential to impact the broader ocean and global carbon cycling due to the significant water exchange with the adjacent ocean (Bauer et al., 2013).

As carbonate ion concentrations continue to decrease, the water's buffering capacity also decreases and the ability of the ocean to absorb more $\mathrm{CO}_{2}$ from the atmosphere diminishes (Sabine et al., 2004). Small environmental changes induced by climate change can reduce $\mathrm{CO}_{2}$ sequestration despite increasing atmospheric $\mathrm{CO}_{2}$, consequently leaving more $\mathrm{CO}_{2}$ stuck in the atmosphere (Bush, 2019). As the ocean sequesters increased atmospheric $\mathrm{CO}_{2}$, it is critical to track and identify potential inputs from coastal environments like estuaries. Using river discharge rates into the bay and concentrations of DIC and ALK, Brodeur et al found that export rates in the Chesapeake Bay rates fluctuated with the season (Brodeur et al., 2019). Further studies of the creek discharge rates and fluxes into the Morro Bay Estuary would give us a better idea if the estuary is a potential DIC and ALK source to the adjacent ocean (Brodeur et al., 2019). 


\subsection{Seagrass as a Natural Sequestration Tool}

Seagrass is a potential carbon sequestration tool due to its uptake of $\mathrm{CO}_{2}$ for primary production. As water moves into the seagrass beds, photosynthesis and carbon burial within the mud both draw down $\mathrm{CO}_{2}$ and help increase the $\mathrm{pH}$ (Figure 4.2).

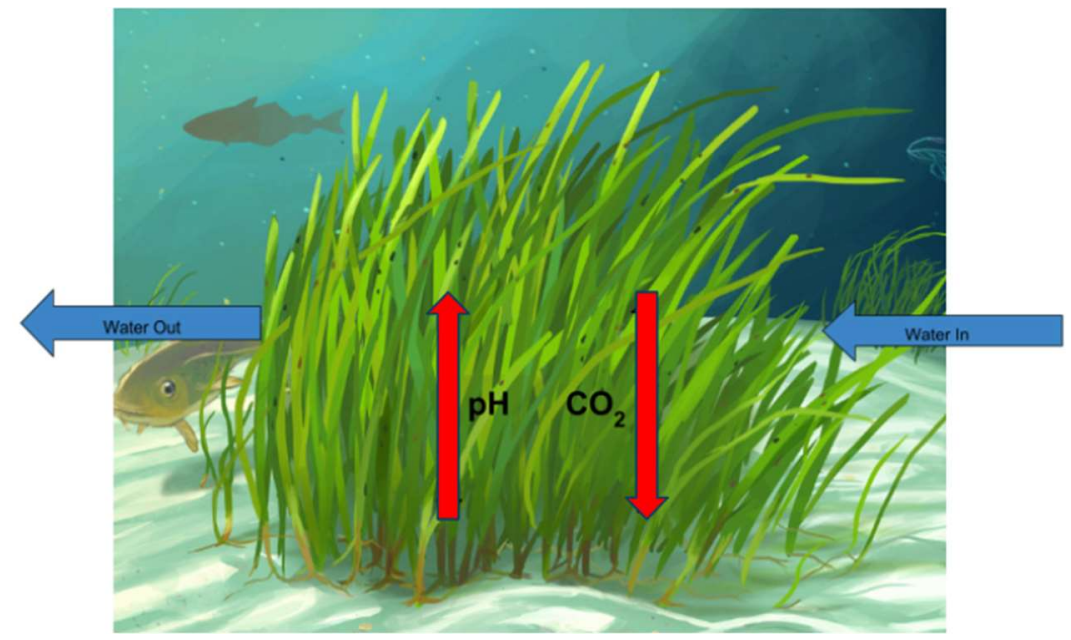

Figure 16. Simple Schematic of the Role Seagrass Plays in Mitigating Water Acidity. Increased carbon sequestration into seagrass beds results in lower DIC $\left(\mathrm{CO}_{2}\right)$ and increased $\mathrm{pH}$ levels.

Experimentation is currently underway to quantify the effectiveness of utilizing seagrass meadows for carbon sequestration to reduce the effects of localized ocean acidification (Seabird Scientific, 2018). Effectiveness of seagrasses as a mitigation tool will depend on the amount of sequestration occurring within the beds and comparing this to the existing seasonal variations. In Puget Sound, Washington, $\mathrm{pH}$ sensors have recently been deployed in seagrass beds in an attempt to quantify their carbon sequestration effectiveness (Seabird Scientific, 2018). A 2018 study in Tomales Bay, California found that small patches of seagrass meadows have the potential to buffer $\mathrm{pH}$ by $0.1-0.2$ units on a localized short-term scale, which is estimated to provide up to a $16 \%$ increase in organism calcification (Koweek et al, 2018). Pacella et al found that increased anthropogenic $\mathrm{CO}_{2}$ reduces the ability of the system to buffer natural extremes in $\mathrm{CO}_{2}$, thus amplifying natural fluctuations of $\mathrm{pH}$ and DIC (Pacella et al., 2017). This leads us to believe that increased DIC levels in the back bay could potentially be mitigated by eelgrass. Also, the recent loss of eelgrass populations is likely affecting the buffering capacity within Morro Bay. 
It further supports the restoration work that is currently being done by the National Estuary Program (NEP) to reintroduce a healthy population to the bay that can help mitigate the effects of ocean acidification.

\subsection{Uncharacterized Contributions to Total Alkalinity}

Due to the high ALK levels observed in the back bay and towards the shore, we hypothesize that other inputs are contributing to the ALK.

\subsubsection{Watershed Implications}

We observed variations in carbonate chemistry throughout Morro Bay during both transect and shore sampling thus indicating the presence of other inputs influencing the water such as groundwater seepage and runoff from increased urbanization (Figure 4.1). The aquifer in Los Osos has contained high levels of nitrates from both septic discharge and runoff from farming since 1988 (Wilson, 2015). A 2011 study in Los Osos that focused on nitrate concentrations within Morro Bay, found that the groundwater contributed, on average, $46 \%$ of the total nitrate into the bay, with minimum groundwater volumes seeping between April and May and max volumes seeping during late Summer to Winter months (Nadia et al, 2011). Increased nitrate inputs can increase eutrophication, further hindering the natural buffering capacity within the bay and could contribute to the varying carbonate chemistry observed towards the back bay. This could also indicate that other nutrients, such as ammonium and phosphate, are also entering the bay and are further elevating the ALK levels. 


\subsubsection{Contribution of Organic Matter}

Organic alkalinity is of concern in environments with substantial dissolved organic carbon (DOC) and restricted mixing like Morro Bay (Hernandez-Ayon et al., 2007). Although not included in the formal definition of total alkalinity (Dickson 2016), organic matter is thought to potentially contribute significantly to ALK in estuarine and coastal ocean waters and can significantly overestimate the transfer of $\mathrm{CO}_{2}$ to the atmosphere, further creating inaccurate carbonate chemistry models (Hunt et al., 2011). The current understanding of ALK only accounts for inorganic contributions. Any acid-base system with a $\mathrm{pK}_{\mathrm{a}}$ in the range will be titrated and included in the reported total alkalinity. In the open ocean, it is assumed that organic acids and bases are negligible (Fong 2019).

During our analysis, samples were not filtered. Previous studies have found that titration with unfiltered phytoplankton and bacteria can contribute up to $5 \mu \mathrm{mol} \mathrm{\textrm {kg } ^ { - 1 }}$ to the measured ALK (Hyun-Cheol et al. 2006; Hernandez-Ayon et al, 2007, Kim et al., 2006). Although this does not explain the total increase in ALK in the back bay, this could explain some of the observed increase in ALK. At both the Northern Gulf of California and San Diego Bay, organic alkalinity contributions increased as sampling moved further from the mouth (Hernandez-Ayon et al., 2007). This is similar to our observations of increased ALK towards the back bay and further indicates the likelihood of organic alkalinity present in the Morro Bay Estuary. 
Chapter 5

\section{FUTURE WORK}

This study is the start of long-term continuous monitoring of the carbonate chemistry of the Morro Bay Estuary. The goal of this study is to begin the initial chemical characterization of the bay, with the plan to compare these studies in future years as climate change continues to impact the small coastal estuary. Sampling locations established in this study will be sampled monthly to continuously monitor throughout seasons and years.

Autonomous $\mathrm{pH}$ sensors have recently been deployed to continuously monitor high-frequency fluctuations in $\mathrm{pH}$ associated with tidal and diurnal controls. Through this, further evaluation can be done to see how the eelgrass plays a role in mitigating ocean acidification. As the NEP is working on replanting the Z. marina beds, another future study is to measure ALK, DIC and pH inside and outside the eelgrass beds to further investigate the role vegetation has within the broader ecosystem.

Cal Poly Biologists, physical and chemical oceanographers, and engineers, alongside the NEP are all continuously working on monitoring the dynamic processes within the estuary. As the longterm monitoring project progresses, we hope to be able to further investigate the complex processes happening within the estuary and to track the various inputs. Analysis and data collection will help provide a possible explanation for the loss of eelgrass within the estuary. Data collection will also provide valuable information to further improve and increase awareness to the way engineers build and manage areas around sensitive areas. Any input, such as runoff from the neighboring watershed, can affect the local water quality and ecosystem balance, further amplifying the impacts of ocean acidification. This can have larger implications on not only the environment, but also the economy that relies on the health of the Morro Bay Estuary for tourism and oyster farming. Designing ways to help reduce our input into areas such as Morro Bay will help lessen the impact of climate change and protect our natural resources. This all starts with 
understanding the carbonate chemistry in the estuary. The Morro Bay Estuary will hopefully provide a case study for other small low-inflow estuaries that are also experiencing similar impacts of ocean acidification. 


\section{WORKS CITED}

Bauer, J., Cai, W., Raymond, P., Bianchi, T., Hopkinson, C., \& Regnier, P. (2013). The changing carbon cycle of the coastal ocean. Nature.

Bay, M. (2017). Morro Bay National Estuary Program Morro Bay Eelgrass Report.

Bockmon, E., \& Dickson, A. (2015). An inter-laboratory comparison assessing the quality of seawater carbon dioxide measurements. Marine Chemistry, 171, 36-43.

Brodeur, J., Chen, B., Su, J., Xu, Y.-Y., Hussain, N., Scaboo, K., Cai, W.-J. (2019). Chesapeake Bay Inorganic Carbon: Spatial Distribution and Seasonal Variability. Frontiers in Marine Science, 6.

Bust, E. (2019). The ocean absorbs billions of tons of carbon every year, and the process is accelerating, study shows - C-CAN. Retrieved from https://c-can.info/2019/03/15/theocean-absorbs-billions-of-tons-of-carbon-every-year-and-the-process-is-acceleratingstudy-shows/

Caffrey, J., Chapin, T., Jannasch, H., \& Haskins, J. (2007). High nutrient pulses, tidal mixing and biological response in a small California estuary: Variability in nutrient concentrations from decadal to hourly time scales. Estuarine, Coastal and Shelf Science.

Cai, W., Hu, X., Huang, W., Murrell, M., Lehrter, J., Lohrenz, S., Gong, G. (201). Acidification of subsurface coastal waters enhanced by eutrophication. Nature Geoscience, 4(11), 766770 .

Cai, W.-J., Wang, Y., \& Hodson, R. (1998). Acid-base properties of dissolved organic matter in the estuarine waters of Georgia, USA.

Cai, W.-J., Wang, Y., Krest, J., \& Moore, W. (2003). The geochemistry of dissolved inorganic carbon in a surficial groundwater aquifer in North Inlet, South Carolina, and the carbon fluxes to the coastal ocean. Science Direct.

Carter, B., Radich, J., Doyle, H., \& Dickson, A. (2013). An automated system for spectrophotometric seawater pH measurements. Limnology and Oceanography: Methods.

Cyronak, T., Andersson, A., D’Angelo, S., Bresnahan, P., Davidson, C., Griffin, A., White, M. (2018). Short-Term Spatial and Temporal Carbonate Chemistry Variability in Two Contrasting Seagrass Meadows: Implications for pH Buffering Capacities. Estuaries and Coasts.

Dickson, A., Afghan, J., \& Anderson, G. (2003). Reference materials for oceanic CO2analysis: A method for the certification of total alkalinity. Marine Chemistry.

Doney et al. (2009).

Duarte, C., Hendriks, I., Moore, T., Olsen, Y., Steckbauer, A., Ramajo, L.,Mcculloch, M. (2013.). Is Ocean Acidification an Open-Ocean Syndrome? Understanding Anthropogenic Impacts on Seawater $\mathrm{pH}$.Science Direct.

Fong, M., \& Dickson, A. (2019). Insights from GO-SHIP hydrography data into the thermodynamic consistency of CO2 system measurements in seawater. Marine Chemistry, 211, 52-63. 
Hunt, C., Salisbury, J., \& Vandemark, D. (2011). Contribution of non-carbonate anions to total alkalinity and overestimation of pCO 2 in New England and New Brunswick rivers. Biogeosciences, 8, 3069-3076.

J. Martín Hernández-Ayon, Alberto Zirino, A. G. Dickson, T.-V. (2007). Estimating the contribution of organic bases from microalgae to the titration alkalinity in coastal seawaters. Association of Limeography and Oceanogrpahy.

J. Martín Hernández-Ayon, Alberto Zirino, A. G. Dickson, Tania Camiro-Vargas and E. Valenzuela.(2007) Estimating the contribution of organic bases from microalgae to the titration alkalinity in coastal seawaters. Limnol. Oceanogr.: Methods 5, 2007, 225-232.

Johannessen, S., \& Macdonald, R. (2016). Geoengineering with seagrasses: Is credit due where credit is given? Environmental Research Letters.

Khatiwala, S., Primeau, F., \& Hall, T. (2009). Reconstruction of the history of anthropogenic CO2 concentrations in the ocean. Nature, 462(7271), 346-349.

Kim, H.-C., Lee, K., \& Choi, W. (2006). Contribution of phytoplankton and bacterial cells to the measured alkalinity of seawater. Association of Limeography and Oceanography.

Koweek, D., Zimmerman, R., Hewett, K., Gaylord, B., Giddings, S., Nickols, K., Caldeira, K. (2018). Expected limits on the ocean acidification buffering potential of a temperate seagrass meadow. Ecological Applications.

Lueker, T., Dickson, A., \& Keeling, C. (2000). Ocean pCO calculated from dissolved inorganic carbon, 2 alkalinity, and equations for $\mathrm{K}$ and $\mathrm{K}$ : validation based on 12 laboratory measurements of $\mathrm{CO}$ in gas and seawater at 2 equilibrium. Science Direct.

Middelburg, J. (2019). Biogeochemical Processes and Inorganic Carbon Dynamics. Marine Carbon Biogeochemistry.

Millero, F. (2007). The Marine Inorganic Carbon Cycle. Chemical Reviews, 107(2), 308-341.

Morro Bay National Estuary Program. (2012). Morro Bay National Estuary Program Comprehensive Conservation Management Plan.

Morro Bay National Estuary Program State of the Bay. (2017).

Mosley, L., Husheer, S., \& Hunter, K. (2004). Spectrophotometric pH measurement in estuaries using thymol blue and m-cresol purple. Marine Chemistry.

Nadia, J., \& Weston, J. (2011). Quantification of Nitrate Sources and Sinks using a Water Quality Network in Morro Bay Estuary, California. Digital Commons, Cal Poly.

Nielsen, A., Nielsen, K., Stachowicz, J., Boyer, K., Bracken, M., Chan, F., Capece, L. (2018).Seagrass and Kelp as an Ocean Acidification Management Tool in California. Working Group Members California Ocean Science Trust.

Ortega, T., Ponce, R., Forja, J., \& Gó Mez-Parra, A. (2004). Fluxes of dissolved inorganic carbon in three estuarine systems of the Cantabrian Sea (north of Spain). Science Direct.

Paulsen, M., Andersson, A., Aluwihare, L., Cyronak, T., D'Angelo, S., Davidson, C., . . . Schroeter, S. (2018). Temporal Changes in Seawater Carbonate Chemistry and Carbon Export from a Southern California Estuary. Estuaries and Coasts, 41(4), 1050-1068.

Pimenta, A., \& Grear, J. (2018). Guidelines for Measuring Changes in Seawater pH and Associated Carbonate Chemistry in Coastal Environments of the Eastern United States. 
Rasmusson, L., Lauritano, C., Procaccini, G., Gullström, M., Buapet, P., \& Björk, M. (2017). Respiratory oxygen consumption in the seagrass Zostera marina varies on a diel basis and is partly affected by light. Marine biology, 164(6), 140.

Sabine, C., Feely, R., Gruber, N., Key, R., Lee, K., Bullister, J., Rios, A. (2004). The Oceanic Sink for Anthropogenic CO 2. Science Vol. 305

Sea Bird Scientific. (2018). Field Testing the Alpha SeapHOx.

SOP $3 b$ - Total alkalinity (open cell) SOP $3 b$ Determination of total alkalinity in sea water using an open-cell titration. EPA. (2016).

US Army Corps of Engineers. (2013). Draft Environmental Assessment Morro Bay Six Year Federal Maintenance Dredging Program.

US Climate Data. (2019). Climate Morro Bay - California and Weather averages Morro Bay. Retrieved from https://www.usclimatedata.com/climate/morro-bay/california/unitedstates/usca0733

Walter, R. (2017). Physical Drivers of Morro Bay Estuary, Personal Communication.

Wilson, N. (2015). Los Osos groundwater is in danger, and its rescue will be costly. 